\title{
External Adjustment and the Global Crisis ${ }^{*}$

\author{
Philip R. Lane \\ IIIS, Trinity College Dublin and CEPR
}

\author{
Gian Maria Milesi-Ferretti \\ International Monetary Fund and CEPR
}

First draft: May 30th 2011

This draft: December 8th, 2011

\begin{abstract}
The period preceding the global financial crisis was characterized by a substantial widening of current account imbalances across the world. Since the onset of the crisis, these imbalances have contracted to a significant extent. In this paper, we analyze the ongoing process of external adjustment in advanced economies and emerging markets. We find that countries whose precrisis current account balances were in excess of what could be explained by standard economic fundamentals have experienced the largest contractions in their external balance. We subsequently examine the contributions of real exchange rates, domestic demand and domestic output to the adjustment process (allowing for differences across exchange rate regimes) and find that external adjustment in deficit countries was achieved primarily through demand compression, rather than expenditure switching. Finally, we show that changes in other investment flows were the main channel of financial account adjustment, with official external assistance and ECB liquidity cushioning the exit of private capital flows for some countries.
\end{abstract}

Keywords: global crisis, current account adjustment.

JEL Classification: F31, F32

\footnotetext{
* Revised version of paper prepared for the NBER-Sloan Global Financial Crisis Conference, Bretton Woods, June 3-4 2011. We thank the anonymous referees, our discussant Richard Portes, the organizers, the participants in the conference and pre-conference and seminars at INSEAD and Trinity College Dublin for helpful feedback. Peter McQuade and Clemens Struck provided helpful research assistance. Email: plane@,tcd.ie, gmilesiferretti@imf.org. The views expressed in this paper are those of the authors and do not necessarily reflect those of the IMF or IMF policy.
} 


\section{INTRODUCTION}

The period preceding the global financial crisis that began in 2008 was characterized by widening current account imbalances across the globe, reflecting a variety of factors: rising oil prices, credit booms and asset price bubbles, and generally easy external financing conditions. The global crisis was associated with a dramatic change in these conditions: sharp declines in asset prices and oil prices, tightening credit, and a drying-up of external finance for several heavily indebted countries, some of which turned to external assistance from the IMF and the European Union. Evidence on the impact of the crisis on output and demand suggests that countries running large current account deficits during the pre-crisis years were the most severely affected, with declines in domestic demand being particularly dramatic (Lane and Milesi-Ferretti, 2011).

In this paper, we analyze the external adjustment process following the financial crisis. Our hypothesis is that pre-crisis current account imbalances widened beyond levels consistent with sustainable medium-term positions. The emergence of large imbalances was facilitated by a benign global financial environment, with low risk aversion among lenders and borrowers coupled with over-optimistic expectations about future growth in deficit countries and amplification mechanisms associated with rising housing and financial asset prices in recipient countries. ${ }^{1}$ As a result, a number of countries borrowed heavily, with net external liabilities quickly expanding. For example, in 2000 average net external liabilities were around 36 percent of GDP in Greece, Portugal, and Spain, and around 38 percent of GDP in the Baltics. By the end of 2007, average net external liabilities amounted to 87 percent of GDP in the three euro countries and close to 70 percent of GDP in the Baltics. After this rapid expansion in external liabilities, external conditions changed drastically during the crisis, triggering a painful process of current account adjustment.

\footnotetext{
${ }^{1}$ On the relation between housing prices and current account balances see, for example, Aizenman and Jinjarak
} (2008). 
In our empirical analysis, we first seek to establish the extent to which current account balances prior to the crisis exceeded levels consistent with underlying economic fundamentals. We next ask whether the current account adjustment following the crisis was indeed sharper in countries where pre-crisis "excesses" were more evident. The answer to this question is a resounding yes-countries whose current account balances were in excess of what could be explained by standard economic fundamentals prior to the crisis also experienced the largest contractions in their external balance.

We subsequently examine how external adjustment has taken place. Have real exchange rate movements contributed through an expenditure-switching channel? Or has expenditure reduction been the primary mechanism for the closing of excessive deficits? Has the adjustment experience differed between countries with fixed versus flexible exchange rate regimes? The evidence suggests that the adjustment in deficit countries took place primarily through a compression of output and demand. In fact, among pegging countries, real effective exchange rates tended to appreciate in countries experiencing reductions in the current account deficit, while the correlation between changes in real exchange rates and changes in the current account balance was only weakly negative in countries with an intermediate or floating regime. Finally, we turn to a closer examination of the behavior of capital flows during this period. We ask two questions. First, we investigate what types of flows were associated with changes in current account balances. Second, we explore the role played by official flows (including automatic flows among member central banks within the euro area) in the adjustment process.

Our contribution is linked to the literature on global imbalances (see, for example, Obstfeld and Rogoff, 2010 and Blanchard and Milesi-Ferretti, 2010 for recent discussions). However, our focus is on the evolution of the current account balances relative to domestic GDP across a wide range of advanced economies and emerging markets, rather than on the absolute size of cross- 
border borrowing and lending. Our paper is also related to the burgeoning empirical literature seeking to explain medium-term current account behavior across countries (see, for example, Chinn and Prasad, 2003, Gruber and Kamin, 2007, Chinn and Ito, 2007, Lee et al, 2008 and Gagnon, 2011). While our empirical medium-term current account model is very related to the ones used in those papers, our primary goal is exploit the model to construct a "fitted" current account series that allows us to check whether current account movements after the crisis have gone in the general direction of reducing divergences between actual and fitted current account balances. Finally, our work is linked to the literature on current account reversals and sudden stops (see Milesi-Ferretti and Razin 2000, Edwards 2003, Adalet and Eichengreen 2007 and Freund and Warnock 2007, amongst others). While that literature largely focuses on country episodes of large current account improvements drawn from different time periods, we analyze the cross-section of current account adjustment for a specific time period, simultaneously looking at both deficit and surplus countries.

The remainder of the paper is organized as follows. Section II presents some stylized facts about the behavior of current account balances during the crisis and also provides a brief review of the theoretical literature on the external adjustment process in the event of a global financial shock. Section III presents an empirical analysis of current account behavior and adjustment mechanisms and also discusses alternative hypotheses on the factors driving post-crisis current account adjustment. Section IV concludes.

\section{THE COMPRESSION IN CURRENT ACCOUNT BALANCES, 2008-2010}

Figure 1 plots the standard deviation of the cross-country distribution of current account 
balances (expressed as ratios to GDP) over the 1995 to 2010 period. $^{2}$ The figure captures the sustained increase in dispersion over 1997 to 2008, with an especially sharp increase from 2004 onwards, followed by a substantial compression since 2008. Figure 2 provides a selective view of the size of current account adjustment in different countries and regions. In particular, the figure shows the dramatic reduction in current account deficits in Central and Eastern Europe, the sizable but much smaller reduction in deficits in the euro area periphery, as well as the substantial decline in current account surpluses in China and oil exporters. The figure also illustrates that changes in the "oil balance" did not play a central role in the adjustment, with the rebound in oil prices in 2010 offsetting the decline in the early stages of the crisis.

Our baseline view is that the process of widening current account imbalances during the period preceding the full-blown crisis (in particular 2005 to mid-2008) reflected a variety of factors, among which asset price booms and easy access to external finance were particularly crucial. ${ }^{3}$ The crisis was associated with a sharp increase in risk aversion, declining asset prices, and significant downward revisions to growth expectations for a variety of countries. Indicators such as the VIX on the S\&P 500 or the corporate bond spread between AAA-rated and BAA-rated bonds clearly point to tighter financial conditions.

In terms of a conceptual framework, the body of work on 'sudden stops' (that is, rapid narrowing of external imbalances) is clearly relevant for analyzing the experience of deficit countries. ${ }^{4}$ In particular, models in which there is a global change in financial conditions are helpful in thinking about the compression in the cross-country distribution of current account

\footnotetext{
2 Our focus in this paper is on external balances vis-à-vis each country's GDP, since we are interested in countrylevel macroeconomic adjustment issues. For other purposes - for example, tracking global imbalances-it would be more appropriate to scale imbalances by global GDP.

${ }^{3}$ See Blanchard and Milesi-Ferretti (2010) for a narrative of the different phases of global imbalances.

${ }^{4}$ Mendoza (2010) is one prominent recent example.
} 
imbalances. ${ }^{5}$ Furthermore, viewing the crisis as a global financial shock is desirable since such a perspective is also capable of explaining the enormous decline in gross capital flows during the most acute phase of the crisis (Forbes and Warnock, 2011, Milesi-Ferretti and Tille, 2011). ${ }^{6}$

Such a global financial shock might be captured by an increase in the risk premium charged on external liabilities or by an increase in financial home bias. For instance, Blanchard et al (2010) develop a model of a small, emerging economy in which these different types of shocks can be analyzed, and show that both an increase in financial home bias and an increase in the risk premium are associated with a narrowing of the external balance and a decline in domestic output. ${ }^{7}$ Similarly, in the IMF's Global Economic Model, a general-equilibrium macroeconomic model of the world economy, an increase in the risk premium on external debt can be shown to deliver a reduction in external imbalances and a decline in output in debtor countries (see, amongst others, Lane and Milesi-Ferretti 2007). The recessionary impact of a sharp decline in net capital inflows is a function of the negative impact on domestic demand in an environment with nominal rigidities. Furthermore, the negative impact on output can be amplified in the presence of credit market frictions by which the associated declines in domestic asset prices generate negative feedback loops through the collateral channel (see Mendoza 2010, amongst others).

A common theme in this literature is that the impact of a sudden stop will differ across exchange rate regimes (Obstfeld and Rogoff 2001, 2007a, 2007b; Lane and Milesi-Ferretti 2007). Under most configurations, if a country is unable to offset the domestic demand shock through expansionary monetary policy and/or accomplish real exchange rate adjustment through

\footnotetext{
${ }^{5}$ For the purpose of looking at adjustment over a two-year window, we view the crisis as a global financial shock, even if was initially concentrated in the U.S. before turning global in late 2008. 6 A shortcut is provided by Obstfeld and Rogoff (2001, 2007a, 2007b). These authors simply impose a sudden reduction in current account imbalances and work out the implications for real exchange rate behavior. However, since they focus on endowment economies, they cannot provide ancillary hypotheses concerning the behavior of output during sudden stop episodes.

${ }^{7}$ However, the exchange rate response differs across the different types of financial shock.
} 
nominal devaluation, the recessionary impact will be larger than in the case of a flexible exchange rate regime. However, this relies on exchange rates moving in a stabilizing direction, which may not hold if there are shocks in currency markets.

In summary, the main predictions from this interpretative framework are that an adverse shift in global financial conditions should deliver a narrowing in current account imbalances, with deficit countries experiencing real exchange rate depreciation and a decline in relative output. Moreover, the relative contributions of exchange rate adjustment and output adjustment should differ across exchange rate regimes. We empirically investigate these questions in the next section.

Finally, there are some alternatives to our proposed interpretative framework. For example, a generalized decline in availability of external finance (say because of an investor panic) could imply a bigger contraction in current account balances in countries with larger deficits, without implying that pre-crisis deficits were "excessive." Alternatively, some omitted variable explaining pre-crisis current account balances may have shifted during the crisis. In the robustness section below, we address some of these alternative hypotheses.

\section{PRE-CRISIS FACTORS AND CURRENT ACCOUNT ADJUSTMENT}

In this section, we ask whether pre-crisis variables help to explain the change in the current account during the crisis. In particular, we investigate whether the current account adjustment which occurred during the crisis can be viewed as correcting "excessive" imbalances that may have emerged during the pre-crisis period. The prevailing narrative of the $2005-2008$ period is that the sharp increase in the dispersion of current account balances during this period may in part be attributed to a financial environment characterized by low global interest rates, increased risk tolerance among global investors and/or increased risk taking among deficit countries. 
Under this view, current account imbalances had an unsustainable component during this period that was due for elimination once the froth in credit markets dissipated.

In order to investigate this question, it is necessary to have an estimate of the "equilibrium" distribution of current account balances during the pre-crisis period, since a zero balance is not the right benchmark for most countries. As is attested by an extensive empirical literature, persistent differences in current account balances can be linked to a set of macroeconomic fundamentals. Our strategy is to estimate the equilibrium current account balances for the precrisis period that would be indicated by these fundamentals. In turn, we capture the "excess" component of current account imbalances as the deviation from these estimated equilibrium values. Subsequently, we use this measured gap between the actual current account balances and their model-fitted values for the period 2005-08, and we then examine whether external adjustment during the crisis can be related to the size of this gap measure.

III.1 Estimating “excess” pre-crisis current account imbalances

Accordingly, the first step is to construct a standard empirical model of medium-term current account determination (as in Chinn and Prasad, 2003; Gruber and Kamin, 2007; Lee et al., 2008; Gagnon, 2011). ${ }^{8}$ The current account equation is estimated over the period 1969-2008, with the current account and its explanatory variables measured as 4-year averages to smooth businesscycle fluctuations. We consider the following empirical specification:

$$
C A_{i t}=\alpha+\sum_{j} \beta^{j} X_{i t}^{j}+\varepsilon_{i t}
$$

\footnotetext{
${ }^{8}$ In some cases (such as Lane and Milesi-Ferretti 2002), the focus is on equilibrium net foreign asset positions rather that the equilibrium current account balance.
} 
where $C A_{i t}$ is the current account (expressed as a ratio to GDP) and $X_{i t}^{j}$ are explanatory

variables. The selection of regressors largely follows the specifications reported in the previous literature. In particular, this general approach is also employed by the IMF in assessing mediumterm current account equilibria (see Lee et al 2008). Where appropriate, variables are measured in relative terms, since only idiosyncratic shifts in fundamentals should affect the current account.

The specific regressors are:

- The relative fiscal balance (expressed as a ratio to GDP and measured relative to a weightedaverage of the fiscal balance of country i's trading partners). Its inclusion is motivated by the many factors that can induce a departure from Ricardian Equivalence (see also Lane and Milesi-Ferretti 2002) and its expected sign is positive. ${ }^{9}$

- The GDP growth rate (measured relative to a weighted-average of the growth rates of country i's trading partners), included to capture the strength of convergence factors, and is expected to be negatively correlated with the current account balance.

- The relative level of PPP-adjusted GDP per capita (in logs, relative to a weighted-average of country i's trading partners), included to capture the convergence process — to the extent that the income level is a proxy for the marginal product of capital. Its expected sign is positive.

- The old-age dependency ratio (defined as the ratio of the population aged 65 and older to the working-age population, and measured relative to a weighted average of country i's trading

\footnotetext{
${ }^{9}$ In principle, temporary fluctuations in government consumption or investment may matter for the current account (regardless whether deficit-financed or tax-financed). However, such temporary fluctuations may be more important in higher-frequency data than in explaining the medium-term variation in current account balances. See also Abbas et al (2010).
} 
partners). This variable is expected to have a negative impact on the current account balance because retirees typically draw down their savings.

- The population growth rate (measured relative to a weighted-average of country i's trading partners). This variable is expected to have a negative effect on the current account balance (as the very young do not save).

- The aging rate. This variable is new in the literature. ${ }^{10}$ It is defined as the expected change in the old-age dependency ratio in the future (constructed as the difference between the age dependency ratio in year $t+20$ and the ratio in year $\mathrm{t}$, where the $t+20$ estimate is based on United Nations population projections). Ceteris paribus, we would expect countries where the population is getting old more rapidly to have higher saving.

- The net export position in oil (expressed as a ratio to GDP) as well as its interaction with a Norwegian country dummy. The oil balance is included to capture the impact of fluctuations in the oil price (given the different extent of "oil intensity" in production and relatively rigid demand in oil importers). We also allow the oil balance to play a different role for Norway, in view of the country-specific institutional arrangements that govern the management of its oil revenues.

- The lagged value of the net foreign asset position expressed as a ratio to GDP (say, NFA/GDP at end-2004 for the 2005-08 period). It is included since the steady-state current account balance should be proportional to the equilibrium net foreign asset position in a growing economy, and has a positive expected sign.

10 See also Lane (2010). 
- A crisis dummy variable capturing whether a country is experiencing a major economic crisis in year $t$, included to capture the disruption in access to capital markets for countries undergoing a financial crisis. It is expected to have a positive coefficient.

- An Asian crisis dummy variable that takes the value 1 for 1997-2000 for those Asian economies at the center of the Asian financial crisis and 0 otherwise. It is included to capture the specific disruptions associated with the 1997-2000 period in Asia, and is expected to have a positive sign.

- A dummy variable capturing whether a country is a major center for international financial trade. The financial center dummy is relevant, in view of the possible measurement errors in tracking net capital flows for centers of international wholesale asset trade.

- The terms of trade, included to capture the effects of changes in world market prices for a country's exports or imports (in addition to oil prices). It is expected to have a positive sign.

Our country sample includes 65 advanced economies and emerging markets (listed in the Appendix). We exclude countries that are oil exporters as well as countries with per capita income in 2007 below $\$ 1000$ and very small countries (with GDP below $\$ 20$ billion in 2007). The rationale for excluding oil exporters is the extreme dependence of their current account balance on the price of oil. ${ }^{11}$ The rationale for excluding low-income countries is two-fold: first, the evolution of their current account balance is affected by specific factors such as external aid, and second, many of these countries had periods of extreme current account deficits followed by debt reduction and debt forgiveness agreements. In turn, this hinders the ability to conduct meaningful inference on the impact of standard macroeconomic and structural fundamentals on

11 That said, results for a sample including oil exporters are remarkably similar to those presented in the paper. 
the current account. Finally, very small countries may have outsized current account volatility because of factors such as lumpy imports.

The results are presented in Table 1. Our empirical specification aims at explicitly accounting for both the cross-sectional and time-series variation in current account balances, and therefore does not include country-specific fixed effects. ${ }^{12}$ In column (1), we report results for the whole sample; in column (2), we restrict the sample to the set of advanced economies; and we show results for the emerging market subsample in column (3). Columns (4)-(6) repeat the analysis for a specification that also includes the terms of trade (in addition to the oil balance).

In terms of the full-sample results, the specification explains 45 percent of the variation in the current account balances. In terms of individually significant coefficients, the fiscal balance is positive with an estimated coefficient of 0.24 , such that an improvement in the fiscal balance of four percentage points of GDP is associated with a one percentage point improvement in the external balance. In addition, an increase in the relative level of output per capita is correlated with an improvement in the external position. In relation to demographic patterns in the fullsample results, an increase in the old-age dependency ratio is associated with a decline in the current account. The key role of the commodities terms of trade is highlighted by the significant co-movement between the oil balance and the current account. In terms of crisis episodes, the general crisis dummy is significantly positive, with a further positive effect associated with the Asia crisis in particular.

The results in columns (2) and (3) show that many results are quite similar across the advanced and emerging market subsamples. However, the overall explanatory power is twice as large for

12 The cross-sectional dimension provides more explanatory power than the time-series dimension, with the latter particularly important for the impact of demographic variables. 
the advanced group as for the emerging group. In addition, the relative level of GDP per capita plays no role in explaining intra-group variation in external balances. There is also a striking difference in demographic patterns. For the advanced economies, the main demographic effect is that those countries that face a more rapidly ageing population run more positive current account balances, while the current account negatively co-moves with the old-age dependency ratio and the rate of population growth for the emerging group. Finally, within this period, financial crises are a significant influence on the current account balances of emerging economies but not for advanced economies. The pattern of results is quite similar for the regressions in columns (4)-(6); in addition, we find some evidence that stronger terms of trade are associated with improvements in the current account balance for emerging markets.

Two factors contribute to the worse fit for emerging markets, particularly for recent years. The first is the pattern of current account surpluses in emerging Asia after the 1997 crisis. While the Asian crisis dummy captures the turnaround in the current account during the period 1997-2000, the surpluses persisted in several countries in subsequent years as well. The second factor is the very large current account deficits in a number of emerging European economies, such as Bulgaria and the Baltics. ${ }^{13}$

Figure 3 illustrates the capacity of the model to explain the cross-country distribution of current account balances by scattering the actual current account balances for the 2005-2008 crosssection against the fitted values from equation (4) in Table 1. As is clear from the chart, the fit is quite high, with a correlation of 0.74 .

13 Gagnon (2011) obtains a much better "fit" for lower-income countries in his current account regression model. The reason is the inclusion of official capital flows as an explanatory variable for current account balances-for lower-income countries in particular these are the dominant form of flows. However, it is difficult to interpret an equation in which capital flows are an independent driver of the current account balance, controlling for other fundamentals. 
III.2 Current account "gaps" and post-crisis outcomes

Next, we construct a measure of the current account "gap" as the difference between the actual average current account balance during 2005-2008 (the final four-year interval in our sample) and the fitted value from the estimated regression

$$
\operatorname{CAGAP}_{i, 0508}=C A_{i, 0508}-\widehat{C A}_{i, 0508}
$$

We consider $C A G A P_{i 0508}$ as a proxy for the extent of "excess" current account imbalances during the immediate pre-crisis period, in sense that the gap measure reflects current account positions that cannot be linked in a systematic fashion to the fundamentals included in our benchmark specification.

To the extent that the benchmark regression does a good job in capturing the medium-term behavior in the current account, we should expect that those countries with the largest negative gaps should experience the largest subsequent current account improvement during the crisis period and/or should experience the greatest adjustment pressures (as might be captured by real exchange rate and relative demand movements on the real side and capital market pressures on the financial side). Conversely, the gap measure will not be helpful in explaining the subsequent adjustment pattern if we have omitted key fundamental drivers of medium-term current account behavior, unless such omitted fundamentals changed during the crisis period in a way that is consistent with a narrowing of current account balances. ${ }^{14}$

\footnotetext{
14 Although we have included a long list of variables in the panel estimation of equilibrium current account values, there are surely other variables that may be helpful in explaining country-specific patterns. However, if our estimated gap term is fully explained by such omitted variables, it will not be helpful in explaining the subsequent adjustment dynamics unless these omitted variables coincidentally move in a direction during the crisis period that would also drive a closing of current account imbalances.
} 
We use the fitted values from column (4) in Table 1 to calculate the gap measure. This measure is quite robust to alternative specifications to estimate equilibrium current account balances. For example, using the fitted values from the sub-samples reported in columns (5) and (6) in Table 1 generates gap measures that have a correlation above 0.9 with our measure. There are similarly high correlations if we use the expanded current account measure reported in columns (1)-(3) of Table 1. Moreover, if we add extra variables to the current account equation (such as current or capital transfers), this makes little difference to the cross-country variation in the gap term for 2005-2008. Finally, estimating the current account equation using annual data and averaging estimates for the period 2005-08 yields virtually identical results.

We next turn to the relation between the current account gap measure and current account adjustment during the crisis period. Figure 4 plots the change in the current account between 2008 and 2010 against $C A G A P_{i 0508}$. The correlation is clearly negative and very strong, even if we omit the most extreme cases of current account gaps and current account adjustment: the Baltics, Bulgaria, and Iceland.

We next look at this link in a multivariate regression that also conditions on the outstanding stock of net foreign assets at the onset of the crisis, since a global increase in risk aversion may have placed pressure on those countries with the largest outstanding stock of net foreign liabilities, regardless of the level of the current account balance relative to fundamental factors. Accordingly, our baseline regression takes the following form

$$
\Delta C A_{i, 0508-10}=\alpha+\beta C A G A P_{i, 0508}+\gamma N F A_{i, 0407}+\varepsilon_{i}
$$


Where $N F A_{i, 0407}$ is the average ratio of NFA to GDP during the period 2004-07. We expect the improvement in the current account balance between 2005-08 and 2010 to be greatest for those countries with the largest negative current account gaps and - potentially — the largest net foreign liability positions.

We run this regression on a variety of country samples. ${ }^{15}$ In addition to the full sample of 65 countries, we also split the sample between countries that adhere to de facto pegged exchange rate regimes and non-pegging countries, using the classification in Ghosh et al., 2011. The sample of peggers is dominated by EU countries-it includes all euro area countries plus Bulgaria and the Baltics, in addition to a few others such as Hong Kong S.A.R.. Furthermore, we also report variations within these sub-samples. Among the peggers, we drop the Baltic states from some specifications, given the dramatic changes in their current account balances. Among the non-peggers, we drop Iceland from some specifications, given the particularly large depreciation associated with the effective shut-down of the Icelandic krona market during its crisis. Finally, as an alternative to running separate sample splits, we also report full-sample results but with interaction terms to allow for differential effects across exchange rate regimes.

The results are shown in Table 2. Column (1) shows the baseline full-sample estimates. We split the sample between peggers and non-peggers in columns (2)-(3) and (4)-(5), with the latter two columns excluding extreme observations (Iceland among floaters and the Baltics among pegs). Columns (6) and (7) present regressions for the whole sample with regressors interacted with an exchange regime dummy. Across the specifications, the gap measure is significant at the 1

\footnotetext{
${ }^{15}$ We report OLS estimates, with robust standard errors. Although the lagged current account balance implicitly shows up on both sides of the equation, the classical errors-in-variables problem relates to non-persistent errors in the measurement of the current account. We do not consider these to be systematically important in cross-sectional current account data, since the most important types of measurement errors in current account balances tend to be chronic in nature. While the gap measure builds on a "generated" variable, the equilibrium current account variable is generated from a panel estimation over 1969-2008 and it is not clear how estimation could be improved by jointly estimating the 1969-2008 panel and the 2008-2010 cross-section.
} 
percent level, with the exception of column (4) where it is significant at the 10 percent level. The estimated coefficient of 0.57 in column (1) means that over half of the measured current account gap was closed over the 2008 to 2010 period for the typical country in the sample. A comparison of columns (2) and (3) suggests that, for a given current account gap, the size of the subsequent current account adjustment was larger among countries with a pegged exchange rate regime, a result confirmed in column (6).

When extreme observations are dropped (columns (4), (5), and (7)) the difference in adjustment across exchange rate regimes ceases to be statistically significant—-specifically, the dramatic current account adjustment in the Baltics is the main driver of the difference in results across exchange rate regimes. Finally, for pegged exchange rate regimes, there is some evidence in columns (3) and (6) that the size of current account adjustment was smaller in countries with large net foreign asset positions, for a given initial current account gap. Again, the results are driven by the Baltics (compare with columns (5) and (7)), reflecting the fact that these countries had large pre-crisis external liabilities and experienced very large current account adjustment.

We next try to shed some light on the underlying mechanisms by which external adjustment took place during this period. We focus on the cross-country variation in real exchange movements, relative demand and relative output. As a preliminary step, Figures 5-7 show the scatter plots of the real exchange rate, relative domestic demand and relative output against the change in the current account balance between the 2005-08 average and 2010. Figure 5 shows that the bivariate relation between changes in current account balances and changes in the real exchange rate were quite different across exchange rate regimes. For the non-peggers, the scatter shows a negative cross-sectional pattern (the correlation is -0.3), with the Icelandic experience being particularly extreme. For the peggers, the relation is instead positive (correlation is 0.5 ), with larger improvements in the current account associated with real exchange rate appreciation. 
For example, the four currency-board countries in the EU (the Baltics and Bulgaria) experienced dramatic current account corrections without any real depreciation. Instead, Figures 6 and 7 show that changes in current account balances are strongly correlated with changes in relative domestic demand and relative output (correlations are -0.73 and -0.56 , respectively), a relation that holds for both pegged and non-pegged exchange rate regimes. Indeed, the compression of current account deficits was generally associated with steep declines in domestic output and demand relative to the pre-crisis period.

Next, we ask whether changes in the real exchange rate, domestic demand and output can be linked to the size of the pre-crisis current account gap measure. This is relevant, since potential lags in the current account adjustment process mean that some of the adjustment pressure may show up in these variables even if the current account itself is slow to adjust. Moreover, the relation between the current account gap and these variables may be informative about the nature of the adjustment process. Specifically, we estimate the relations between the estimated current account gap for the period 2005-08 and the subsequent cross-country variation in real exchange rate movements and relative demand and output movements. That is, we run regressions of the form

$$
\begin{gathered}
\Delta R E R_{i, 0508-10}=\alpha^{R E R}+\beta^{R E R} C A G A P_{i, 0508}+\gamma^{R E R} N F A_{i, 0407}+\varepsilon_{i}^{R E R} \\
\Delta D D_{i, 0508-10}=\alpha^{D D}+\beta^{D D} C A G A P_{i, 0508}+\gamma^{D D} N F A_{i, 0407}+\varepsilon_{i}^{D D} \\
\Delta Y_{i, 0508-10}=\alpha^{Y}+\beta^{Y} C A G A P_{i, 0508}+\gamma^{Y} N F A_{i, 0407}+\varepsilon_{i}^{Y}
\end{gathered}
$$

where $\Delta R E R_{i, 0508-10}$ is the log change in the real exchange rate between the 2005-08 average and 2010 (a positive movement is a real appreciation), $\Delta D D_{i, 0508-10}$ is the log change in domestic demand between the 2005-08 average and 2010, and $\Delta Y_{i, 0508-10}$ is the log change in relative 
output between the 2005-08 average and $2010 .{ }^{16}$ We expect those countries with larger current account gaps to be under greater pressure to undergo real depreciation and/or experience a relative decline in domestic demand and output. As in the current account regressions, we also control for the initial net foreign asset position.

The regression results for the real exchange rate are shown in Table 3. The current account gap and the net foreign asset position have no explanatory power in the baseline full-sample regression reported in column (1). For floating regimes, we find that the pre-crisis current account gap and net foreign asset position are positively correlated with real exchange rate movements over 2005-08 to 2010 (column (2)). The link between the current account gap and real appreciation disappears, however, if Iceland — an extreme observation, as shown previously in Figure 4-is dropped (column (4)). For the group of countries with an exchange rate peg both the pre-crisis current account gap and net foreign assets are statistically significant (column (3)), but with the opposite sign. That is, within the pegging group the direction of observed real exchange rate movements have been "destabilizing," in the sense that those countries with large negative current account gaps and large net foreign liabilities have experienced real exchange rate appreciation. $^{17}$

Overall, these results suggest that exchange rate adjustment played at most a very modest role in the external adjustment process after the crisis. The pattern of real exchange rate adjustment for peggers may be driven by several factors. First, trade-weighted real exchange rates also depend on fluctuations between the anchor currency and other global currencies (Honohan and Lane 2003, Chen et al 2011). For instance, the euro appreciated by about 10 percent against the dollar

\footnotetext{
16 Using 2007 as the pre-crisis year for trending variables such as output and demand yields even stronger results. ${ }^{17} \mathrm{We}$ also tried an expanded specification in which the terms of trade are an additional regressor. While the terms of trade coefficient is itself significant, its inclusion did not alter the results for our variables of interest. Since the line of causality between the contemporaneous terms of trade and the real exchange rate is complex, we opt to retain our simpler specification in the reported tables.
} 
during 2008-2010, inducing an appreciation in the trade-weighted real exchange rates of the periphery deficit countries (which had large negative current account gaps). Second, if there is persistence in wage or price setting, inflationary momentum that built up in peggers running current account deficits during the pre-crisis boom period may dissipate only slowly. ${ }^{18}$

We turn to an examination of relative domestic demand and relative output dynamics in Table 4. External adjustment for deficit countries requires a reduction in domestic demand relative to its level in trading partners. The full-sample estimates in column (1) show that relative domestic demand grew more slowly, the more negative was the current account gap measure, and the results carry through for both floating and pegged exchange rate regimes, even though for the latter group the coefficient is lower and less precisely estimated (columns (2) and (3)). The main difference between the two groups relates to the role of net foreign assets: for pegged regimes, demand grew more rapidly in countries with higher pre-crisis net foreign assets, while for floating regimes the constant term is higher, but net foreign assets are not associated with faster subsequent demand growth. Results are broadly similar for output dynamics: the coefficient on the pre-crisis gap is somewhat smaller and not statistically significant in the regression for pegged exchange rate regimes only. The smaller magnitudes are consistent with part of the decline in domestic demand mapping into lower imports rather than lower domestic production.

In summary, Tables 2-4 provide a multi-dimensional perspective on how the external imbalances that expanded during 2005-2008 affected country experiences during the subsequent adjustment phase. The regression analysis shows that there has been substantial closure of current account gaps. By and large, current account adjustment in deficit countries has clearly relied more on

18 Another driver of real appreciation might be counter-cyclical markups (Ravn et al, 2006). If the decline in output reflected a negative productivity shock, it might be associated with an increase in the relative price of exports (Backus et al, 1994). Even then, however, it might not generate a real appreciation since it may be offset by a decline in the relative price of nontradables (Benigno and Thoenissen, 2003). Furthermore, the large estimated negative output gaps and high unemployment in countries that experienced a sharp compression of current account deficits casts some doubt on a pure "supply shock" interpretation of the output decline. 
"expenditure reduction" than "expenditure switching." However, the cross-section pattern in real exchange rates shows a weak relation to the current account gap within the group of nonpeggers, while the direction of real exchange rate movements was destabilizing within the group of peggers. Negative current account gaps were associated with sharp declines in relative domestic demand and drops in relative output, with pegged exchange rate regimes with higher net foreign liabilities experiencing larger output and demand declines and vice versa.

Accordingly, the distribution of current account gaps at the onset of the crisis is a good predictor of the distribution of macroeconomic outcomes during the crisis period itself but with some important differences across exchange rate regimes.

\section{III.3 Extensions and robustness checks}

As a first robustness check we investigated whether our results depended on the specific choice of the pre-crisis period (2005-08) in light of the fact that the most virulent phase of the crisis started in the last few months of 2008. We therefore generated the current account gap for the period 2005-07, using a panel regression based on 4-year averages as in the rest of the paper (but 3 years for the last period). In addition, we also estimated the panel using annual data and estimated the current gap by the 3-year average residual over 2005-07. In both cases, the current account gap still displays the same pattern of co-movement with the change in the current account between the pre-crisis period and 2010, as well as with the changes in output growth, domestic demand growth, and real exchange rates. ${ }^{19}$

We also examined whether the relation between pre-current account "gaps" and subsequent outcomes documented in Tables 2-4 depends on whether the current account gap is negative or

19 The results are the same if just the 2007 residual is used as the gap measure or if the panel is estimated for annual data over 1969-2008 and the 2008 residual is used as the gap measure (results available from the authors). 
positive. For example, a compression of current account deficits driven by sustainability concerns could plausibly be related to excess deficits and high pre-crisis liabilities, but there is no symmetric mechanism that would force a more significant adjustment for countries with larger positive current account gaps (see also Blanchard and Milesi-Ferretti, 2011). To be sure, an improvement in current account balances for countries with a negative gap will be accompanied by a worsening in current accounts in other countries in the aggregate, but such compression may or may not be systematically related to the size of the positive gap on a country-by-country basis.

Accordingly, we split the sample between countries with negative gaps and positive gaps to see if adjustment pressures are different across these two groups. The results, presented in Table 5, show that qualitatively the results presented in Tables 3 and 4 hold both for countries with positive pre-crisis current account gaps and countries with negative pre-crisis gaps. However, the magnitude of the co-movement between the current account gap and subsequent changes in the current account balance is much stronger for countries whose current account gaps were negative (that is, for countries whose pre-crisis current account balance was weaker than the level predicted by fundamentals). Similarly, the evidence suggests that pre-crisis current account gaps were more strongly associated with subsequent changes in demand in countries where such gaps were negative. In contrast, the relation between the gap term and the behavior of output is similar across both groups but it is not statistically significant in explaining differences within these groups. Finally, for the negative gap countries, a large negative net foreign asset position is associated with additional downward pressure on domestic demand and output.

Our specification relates current account adjustment during the crisis to the scale of pre-crisis "excess" imbalances. A possible criticism of this approach is that there may be an omitted factor correlated with initial imbalances which is the true underlying driver of current account adjustment. One possible such factor is the scale of pre-crisis fiscal imbalances, since initial fiscal 
imbalances may have triggered fiscal austerity during the crisis, leading to an improvement in the current account. It is also possible that initial fiscal imbalances could have led to a significant change in foreign investors' assessment of domestic risks and hence a large decline in capital inflows, forcing a current account correction. This second story, similar to the one outlined in Section II, sees fiscal imbalances, rather than external imbalances, as playing a dominant role. ${ }^{20}$

While it is clear that in a number of cases investor concerns about fiscal imbalances and/or procyclical fiscal adjustment played an important role in explaining the evolution of the current account, output, and demand, we find no systematic evidence of a strong correlation between pre-crisis fiscal positions and the behavior of the current account (and the related variables) during the crisis period. One reason is that pre-crisis fiscal variables are not a good predictor of the scale of subsequent fiscal adjustment, since countries with apparently healthy pre-crisis fiscal positions (such as Iceland or Ireland) saw dramatic fiscal deterioration during the crisis, with fiscal austerity measures only partly offsetting the operation of automatic stabilizers and/or the assumption of banking-sector liabilities. ${ }^{21}$ Indeed, a sudden stop in capital inflows was plausibly a key driver of fiscal deterioration in some countries, through the adverse impact on domestic output and, via domestic asset prices, the domestic banking sector. Moreover, in some countries, the decline in capital inflows may have prompted activist counter-cyclical fiscal initiatives. In related fashion, large pre-crisis current account deficits in many cases were driven by privatesector external balances.

Table 6 presents the same regressions as in Tables 3 and 5, but adding the ratio of government debt to GDP pre-crisis as an explanatory variable. In columns (1) and (2), where the dependent variable is the change in the current account balance, the coefficient on government debt is

\footnotetext{
${ }^{20}$ We are grateful to Richard Portes for raising this issue in his discussion of our paper.

${ }^{21}$ In addition, the fiscal balance is one of the drivers of our equilibrium current account measure. See also Benetrix and Lane (2010) on the drivers of fiscal positions during the crisis.
} 
actually negative, implying that larger pre-crisis debt is associated with smaller subsequent current account adjustment, after controlling for the current account gap and the pre-crisis external position. Similar results (not presented here) hold if we use the pre-crisis fiscal balance. This does not rule out an impact of pre-crisis fiscal variables on changes in the current account during the crisis, but that impact would occur through the effect of fiscal variables on pre-crisis external variables, rather than independently.

Another possible omitted factor that could explain our pre-crisis current account "gap" are growth expectations. ${ }^{22}$ Specifically, the current account gap for the period 2005-08 may have reflected expectations of rapid economic growth justified by economic fundamentals imperfectly captured by our model. In turn, the crisis could have caused a generalized sudden stop in capital flows because of say, investor panic, and countries with larger pre-crisis "gaps" would have seen their current account respond more strongly to such a shock. To address this possibility, we looked at whether pre-crisis growth expectations (constructed using output growth projections for 2008-12 from the September 2007 World Economic Outlook) are correlated with the 200508 current account gap. The answer is negative: specifically, the correlation between the current account gap and forward-looking growth expectations (whether in levels or differences relative to trading partners) is virtually zero.

A related possible interpretation would be that the narrowing of current account balances was justified by a change in expected future fundamentals, implying a decline in demand for funds in deficit countries at the onset of the crisis even in the absence of a deterioration in the external funding environment. Although, at some level, this proposition is not generally testable, one version of this account is that those countries with the strongest pre-crisis growth rates may have

22 On the link between the current account balance and expectations of future growth for the case of the United States see Engel and Rogers (2006). 
experienced the largest downward revision in growth projections. Accordingly, we collected two vintages of the projected growth rate for 2009-2012 from the September 2007 and the April 2009 editions of the World Economic Outlook. It turns out that the revision in the projected growth rate between these periods is not correlated with the pre-crisis growth rate, but is significantly correlated with the pre-crisis current account gap, consistent with our main narrative by which expectations of a closing of current account deficits is projected to involve a reduction in output growth. ${ }^{23}$ More generally, if the underlying driving force of current account adjustment is a shift in unobserved future fundamentals, this unobserved term must both be correlated with the estimated current account gap and account for the co-variation between the pre-crisis gap measure and the subsequent adjustment patterns in the current account, real exchange rate, domestic demand and output.

As for the generalized sudden stop story, the evidence on capital flows reported in Figure 8 shows clearly that there was a global sudden stop in late 2008-early 2009, but that net flows to emerging markets in 2010 (our post-crisis year) were back to levels comparable to the pre-crisis period. Flows to Central and Eastern Europe slowed considerably, but flows to emerging Asia and Latin America were very strong. The same applies to capital inflows, confirming that there was no generalized sudden stop in flows between the pre-crisis period and 2010.

\section{III.4 Current account adjustment and capital flows}

In the preceding analysis, our primary focus has been on the real implications of the compression in current account balances. In this subsection, we address some issues concerning financial account behavior.

23 These results are available upon request. The results are the same if growth forecasts are measured relative to the growth forecasts for trading partners. 
Table 7 relates the current account gap in 2005-08 to the change in net capital flows between the 2005-08 average and 2010. It partitions the sample between pegs and other exchange rate regimes, and focuses on countries with large current account gaps ( 2 percent of GDP or above in absolute terms). The first two rows of the table (upper and lower parts) highlight the alreadydocumented compression in current account imbalances in countries with large gaps. Subsequent rows indicate the importance of shifts in net other investment flows in financing the shift in current account balances. They also highlight how this shift was particularly large in countries with an exchange rate peg-net inflows declined by close to 9 percent of GDP on average in countries with large negative current account gaps (“excess deficits"), and increased by over 5 percent of GDP in countries with positive current account gaps. The corresponding changes for non-pegged exchange rate regimes are much more modest.

These results are confirmed in simple regression analysis (Table 8). Specifically, we relate the change in different categories of capital flows between the 2005-08 average and 2010 to the size of the current account gap and pre-crisis net foreign assets. Our definition of net capital flows is such that a positive value implies higher net capital inflows in the country. Columns (1)-(3) present results for net other investment flows (capturing net flows in the form of loans, deposits, trade credit etc). Changes in net inflows are strongly positively correlated with both the initial current account gap and the net foreign asset position. This is consistent with the evidence on gross capital flows reported by Milesi-Ferretti and Tille (2011), who show that bank flows have experienced the greatest turnaround during the crisis. Columns (2) and (3) show that the current account gap effect is driven by countries with a pegged exchange rate regime.

Columns (4) and (5) present evidence on net FDI and portfolio flows, respectively (for the full sample only). For both types of net flows there is no systematic relation with the explanatory 
variables, including for sample splits by exchange rate regime (not presented here). Finally, columns (6)-(8) present results for net reserve flows. To interpret results, note that higher accumulation of reserves in 2010 relative to 2005-08 would correspond to a negative value for the dependent variable (since reserves are capital outflows). Results show that non-peg countries with stronger initial net foreign asset position experienced faster reserve accumulation (a result primarily driven by creditor countries such as Singapore and Switzerland), while there is no significant relation of the change in reserve accumulation with the current account gap. For pegged exchange rate regimes, we instead find some evidence of lower reserve accumulation in countries with negative current account gaps. Holding constant other flows, lower reserve accumulation would be associated with an increase in net capital inflows, and hence a worsening of the current account. However, this effect is more than offset for pegged exchange rate regimes by the very large swing in net other investment flows.

The process of external adjustment during the crisis was also characterized by sizable external assistance from multilateral sources. Belarus, Greece, Hungary, Iceland, Latvia, Romania, and Serbia received loans from the International Monetary Fund exceeding 200 percent of their IMF quota during the period 2008-2010, as well as loans from the European Union. In addition, some deficit countries in the euro area (especially, Greece, Ireland, and Portugal) benefited from the cross-border liquidity flows from the ECB that were channeled through the national central bank.

Accordingly, we also investigated whether countries that received official assistance undertook more or less current account adjustment. Results are a priori ambiguous. On the one side, access to official external finance clearly limits the need for an adjustment in net capital flows. On the other side, access to external assistance is not random or exogenous - countries that received external finance were likely among those where the turnaround in private flows was more 
dramatic and hence where the current account adjustment may have been larger.

We proceeded by simply adding a dummy variable for countries that received external assistance to the current account adjustment regressions presented in Table $2 .{ }^{24}$ The results, presented in Table 9, are indeed mixed. For the non-pegger group, the relation between the current account gap and subsequent current account adjustment is weaker, as was already documented in Table 2 , and the coefficient on the official assistance dummy is positive (implying that these countries undertook more adjustment for a given current account gap). For the pegger group, the link between the current account gap and initial net foreign assets on the one hand, and subsequent current account adjustment on the other hand is much stronger. However, the coefficient on the official assistance dummy is instead significantly negative-this implies that these countries undertook less current account adjustment, all else equal, once we control for the size of the current account gap and the initial net external position.

One candidate explanation for the weaker pressure for current account adjustment in those peggers inside the euro area is that liquidity financing from the ECB has cushioned the adverse impact from the reversal in private capital flows. By way of contrast, there was no similar quasiautomatic replacement of private flows elsewhere (including in other pegged regimes such as the Baltic countries or Bulgaria), and hence the sudden stop may have induced more rapid closing of the current account gap for these non-euro countries. Indeed, this is a key mechanism that defines the difference between membership of a currency union with a common central bank and membership of a currency board with no access to the liquidity operations of the anchor central bank.

${ }^{24}$ Given differences in the timing of the provision of official external support it is difficult to devise an appropriate variable capturing the impact of the overall size of support on the 2010 current account balance. 
Given the limited size of the sample of countries receiving external support, it is difficult to test for the effects of liquidity support through the ECB separately from external support through other sources. We instead provide some evidence on the quantitative importance of the Eurosystem as a conduit for capital flows during the crisis in Table 10. The table shows net capital flows via the central bank for each member of the euro area periphery, where the national central bank is the intermediary for liquidity funding from the ECB. These flows were trivial during the pre-crisis period but became very large for Greece, Portugal, and especially for Ireland in 2010 .

\section{CONCLUSIONS}

The large compression in the distribution of current account balances between the pre-crisis period and 2010 provides a laboratory for studying the economics of external adjustment. In our empirical work, we find that cross-country pattern in current account changes during this period is consistent with a correction of "excesses" that had emerged during the pre-crisis period. In terms of adjustment mechanisms, countries that experienced the largest improvements in current account balances had sharper declines (or smaller increases) in output and especially in domestic demand. The behavior of real exchange rates diverged across non-pegger and pegger groups, with the real exchange rate moving in a destabilizing direction for the latter group. Overall, the main channel of external adjustment for deficit countries between the pre-crisis period and 2010 has been expenditure compression, rather than expenditure switching. The evidence also suggests a much stronger link between pre-crisis current account gaps and subsequent current account changes for countries that pre-crisis had negative current account gaps, a finding prima facie consistent with the notion that the adjustment burden has fallen primarily on deficit countries. 
In relation to the financial account, we find that in countries with exchange rate pegs the turnaround in the current account is more strongly related to the initial current account gap than in other countries, and that it took place primarily through a dramatic shift in other investment flows, which include most banking flows. We also find some suggestive evidence that the scale of current account adjustment in countries with a pegged exchange rate has been cushioned by official capital flows-IMF and EU loans but importantly ECB liquidity funds compensated for the exit of private capital flows from major deficit countries.

The high output costs that have been associated with rapidly correcting a large current account deficit during this episode provide additional empirical support for research that assesses whether current account deficits during good times might partly reflect distortions that fail to internalize the risk of a subsequent sudden stop. In turn, the design of optimal policy interventions in such cases is a further item for the future research agenda. A related issue is the extent to which the correction in current account balances will be persistent. The crisis has led to a significant downward revision in potential output in several deficit countries, suggesting that pre-crisis imbalances in deficit countries may have reflected "overheating" at least to some extent. Nevertheless, to the extent that the current account correction in deficit countries was caused by an "undershooting" of output and demand (and therefore reflects negative output gaps) some of the decline in "excess deficits" (and symmetrically of surpluses) could prove to be temporary, unless exchange rate movements allow for more meaningful expenditure switching. But another possibility is that countries with high external liabilities may face persistent external financing constraints-in this case, if price and exchange rate rigidities prevent effective expenditure switching, output may remain below potential for much longer. 


\section{REFERENCES}

Abbas, S.M. Ali, Jacques Bouhga-Hagbe, Antonio J. Fatás, Paolo Mauro and Ricardo C. Velloso (2010), "Fiscal Policy and the Current Account," IMF Working Paper No. 10/121.

Adalet, Muge and Barry Eichengreen (2007), "Current Account Reversals: Always a Problem?," in G7 Current Account Imbalances: Sustainability and Adjustment, edited by Richard Clarida, University of Chicago Press for NBER, 205-246.

Aizenman, Joshua and Y. Jinjarak (2009), "Current Account Patterns and National Real Estate Markets," Journal of Urban Economics 66, 75-89.

Bacchetta, Philippe and Eric van Wincoop (2010), "On the Global Spread of Risk Panics," mimeo, Lausanne and Virginia.

Backus, David K., Patrick J. Kehoe and Finn E. Kydland (1994), "Dynamics of the Trade Balance and the Terms of Trade: The J-Curve?," American Economic Review 84(1), 84-103.

Benetrix, Agustin and Philip R. Lane (2010), “International Differences in Fiscal Policy During the Global Crisis," IIIS Discussion Paper No. 336.

Benigno, Gianluca and Christoph Thoenissen (2003), "Equilibrium Exchange Rates and Supply Side Performance," Economic Journal 113(486), C103-C124. 
Blanchard, Olivier and Gian Maria Milesi-Ferretti (2010), "Global Imbalances: In Midstream," in Reconstructing the World Economy, edited by Il SaKong and Olivier Blanchard, Washington DC: International Monetary Fund.

Blanchard, Olivier and Gian Maria Milesi-Ferretti (2011), “(Why) Should Current Account Balances Be Reduced?” International Monetary Fund Staff Discussion Note 11/03.

Blanchard, Olivier, Mitali Das, and Hamid Faruqee (2010), “The Initial Impact of the Crisis on Emerging Market Countries," Brookings Papers on Economic Activity (Spring), 263-307.

Chen, Ruo, Gian Maria Milesi-Ferretti, and Thierry Tressel (2011), "Euro Area Debtor Countries: External Imbalances in the Euro Area," mimeo, International Monetary Fund.

Chinn, Menzie and Eswar Prasad (2003), "Medium-Term Determinants of Current Accounts in Industrial and Developing Countries: An Empirical Exploration," Journal of International Economics 59, 47-76.

Chinn, Menzie and Hiro Ito (2007), "Current Account Balances, Financial Development and Institutions: Assaying the World 'Saving Glut'," Journal of International Money and Finance 26(4), 546-569.

Chinn, Menzie and Shang-Jin Wei (2008), “A Faith-Based Initiative: Does a Flexible Exchange Rate Regime Really Facilitate Current Account Adjustment?," NBER Working Paper No. 14420. 
Engel, Charles and John H. Rogers (2006), “The U.S. Current Account Deficit and the Expected Share of World Output," Journal of Monetary Economics 53, 1063-93.

Forbes, Kristin J. and Francis E. Warnock (2011), “Capital Flow Waves: Surges, Stops, Flight, and Retrenchment," mimeo, MIT and Darden.

Freund, Caroline and Frank Warnock (2007), “Current Account Deficits in Industrial Countries: The Bigger They Are, The Harder They Fall?," in G7 Current Account Imbalances: Sustainability and Adjustment, edited by Richard Clarida, University of Chicago Press for NBER, 133-168.

Gagnon, Joseph (2011), “Current Accounts Imbalances Coming Back,” PIIE Working Paper No. $11-1$.

Ghosh, Atish R., Jonathan D. Ostry, and Charalambos G. Tsangarides, 2011, “Exchange Rate Regimes and the Stability of the International Monetary System," International Monetary Fund Occasional Paper No. 270, March.

Gruber, Joseph and Steven Kamin (2007), “Explaining the Global Pattern of Current Account Imbalances," Journal of International Money and Finance 26, 500-522.

Honohan, Patrick and Philip R. Lane (2003), “Divergent Inflation Rates under EMU,” Economic Policy 37, 358-394. 
Lane, Philip R. (2010), “International Financial Integration and Japanese Economic Performance," in Japan's Bubble, Deflation and Long-Term Stagnation, edited by Anil Kashyap, Koichi Hamada and David Weinstein, MIT Press, 129-174.

Lane, Philip R. and Gian Maria Milesi-Ferretti (2002), "Long-Term Capital Movements,” NBER Macroeconomics Annual 16, 73-116.

Lane, Philip R. and Gian Maria Milesi-Ferretti (2007), "Europe and Global Imbalances," Economic Policy 22(51), 519-573.

Lane, Philip R. and Gian Maria Milesi-Ferretti (2011), "The Cross-Country Incidence of the Global Crisis," IMF Economic Review 59(1), 77-110.

Lee, Jaewoo, Gian Maria Milesi-Ferretti, Jonathan D. Ostry, Alessandro Prati and Lucca Ricci (2008), “Exchange Rate Assessments: CGER Methodologies,” IMF Occasional Paper No. 261.

Mendoza, Enrique (2010), “Sudden Stops, Financial Crises and Leverage," American Economic Review 100(5), 1941-1966.

Milesi-Ferretti, Gian Maria and Assaf Razin (2000), “Current Account Reversals and Currency Crises: Empirical Regularities," in Currency Crises (Paul Krugman, ed.), University of Chicago Press for NBER.

Milesi-Ferretti, Gian Maria and Cedric Tille (2010), "The Great Retrenchment: International Capital Flows During the Global Financial Crisis," Economic Policy 26(66), 285-342. 
Obstfeld, Maurice and Kenneth Rogoff (2001), "Perspectives on OECD Capital Market Integration: Implications for US Current Account Adjustment," in Global Economic Integration: Opportunities and Challenges, Federal Reserve Bank of Kansas City, 169-208.

Obstfeld, Maurice and Kenneth Rogoff (2007a), “The Unsustainable US Current Account Position Revisited," in G7 Current Account Imbalances: Sustainability and Adjustment (Richard Clarida, ed.), NBER - University of Chicago Press, 339-376.

Obstfeld, Maurice and Kenneth Rogoff (2007b), “Global Current Account Imbalances and Exchange Rate Adjustments," in Brookings Papers on Economic Activity 1, 67-146.

Obstfeld, Maurice and Kenneth Rogoff (2010), "Global Imbalances and the Financial Crisis: Products of Common Causes," in Asia and the Global Financial Crisis (Reuven Glick and Mark Spiegel, eds.), Federal Reserve Bank of San Francisco, 131-172.

Ravn, Morten, Stephanie Schmitt-Grohe and Martin Uribe (2006), "Deep Habits," Review of Economic Studies 73(1), 195-218. 
Appendix. Country sample

\begin{tabular}{|c|c|c|c|c|c|}
\hline country & Peg & Advanced & country & Peg & Advanced \\
\hline Argentina & 0 & 0 & Latvia & 1 & 0 \\
\hline Australia & 0 & 1 & Lithuania & 1 & 0 \\
\hline Austria & 1 & 1 & Luxembourg & 1 & 1 \\
\hline Belarus & 1 & 0 & Malaysia & 0 & 0 \\
\hline Belgium & 1 & 1 & Mexico & 0 & 0 \\
\hline Brazil & 0 & 0 & Morocco & 0 & 0 \\
\hline Bulgaria & 1 & 0 & Netherlands & 1 & 1 \\
\hline Canada & 0 & 1 & New Zealand & 0 & 1 \\
\hline Chile & 0 & 0 & Norway & 0 & 1 \\
\hline China, P.R.: Mainland & 0 & 0 & Pakistan & 0 & 0 \\
\hline China, P.R.: Hong Kong & 1 & 1 & Peru & 0 & 0 \\
\hline Colombia & 0 & 0 & Philippines & 0 & 0 \\
\hline Costa Rica & 0 & 0 & Poland & 0 & 0 \\
\hline Croatia & 1 & 0 & Portugal & 1 & 1 \\
\hline Cyprus & 1 & 1 & Romania & 0 & 0 \\
\hline Czech Republic & 0 & 0 & Russian Federation & 0 & 0 \\
\hline Denmark & 1 & 1 & Serbia, Republic of & 0 & 0 \\
\hline Dominican Republic & 0 & 0 & Singapore & 0 & 1 \\
\hline El Salvador & 1 & 0 & Slovak Republic & 1 & 0 \\
\hline Estonia & 1 & 0 & Slovenia & 1 & 0 \\
\hline Finland & 1 & 1 & South Africa & 0 & 0 \\
\hline France & 1 & 1 & Spain & 1 & 1 \\
\hline Germany & 1 & 1 & Sri Lanka & 0 & 0 \\
\hline Greece & 1 & 1 & Sweden & 0 & 1 \\
\hline Guatemala & 0 & 0 & Switzerland & 0 & 1 \\
\hline Hungary & 0 & 0 & Taiwan & 1 & 0 \\
\hline Iceland & 0 & 1 & Thailand & 0 & 0 \\
\hline India & 0 & 0 & Tunisia & 0 & 0 \\
\hline Indonesia & 0 & 0 & Turkey & 0 & 0 \\
\hline Ireland & 1 & 1 & Ukraine & 0 & 0 \\
\hline Israel & 0 & 1 & United Kingdom & 0 & 1 \\
\hline Italy & 1 & 1 & United States & 0 & 1 \\
\hline Japan & 0 & 1 & Uruguay & 0 & 0 \\
\hline Korea, Republic of & 0 & 0 & & & \\
\hline
\end{tabular}

Notes: "peg" refers to de facto exchange rate regime classification for the period 2005-08. Source: Ghosh et al. (2011) extended by the authors. 
Table 1. Drivers of Current Account Balance, 1969-2008

\begin{tabular}{|c|c|c|c|c|c|c|}
\hline & (1) & (2) & (3) & (4) & (5) & (6) \\
\hline & ALL & ADV & EM & ALL & $\mathrm{ADV}$ & EM \\
\hline Fiscal balance & $\begin{array}{c}0.243^{* * *} \\
(0.06)\end{array}$ & $\begin{array}{c}0.273^{* * * *} \\
(0.04)\end{array}$ & $\begin{array}{c}0.266^{* *} \\
(0.11)\end{array}$ & $\begin{array}{c}0.244 * * * \\
(0.06)\end{array}$ & $\begin{array}{c}0.274 * * * \\
(0.07)\end{array}$ & $\begin{array}{c}0.275^{* *} \\
(0.11)\end{array}$ \\
\hline Growth differential & $\begin{array}{c}-0.072 \\
(0.09)\end{array}$ & $\begin{array}{c}0.32 \\
(0.27)\end{array}$ & $\begin{array}{c}-0.183^{*} \\
(0.09)\end{array}$ & $\begin{array}{l}-0.08 \\
(0.09)\end{array}$ & $\begin{array}{c}0.31 \\
(0.27)\end{array}$ & $\begin{array}{c}-0.20^{* *} \\
(0.09)\end{array}$ \\
\hline Dependency ratio & $\begin{array}{c}-0.15^{* *} \\
(0.06)\end{array}$ & $\begin{array}{c}0.12 \\
(0.14)\end{array}$ & $\begin{array}{c}-0.30^{* * *} \\
(0.10)\end{array}$ & $\begin{array}{c}-0.16^{* *} \\
(0.07)\end{array}$ & $\begin{array}{c}0.13 \\
(0.15)\end{array}$ & $\begin{array}{c}-0.32^{* * *} \\
(0.10)\end{array}$ \\
\hline Population growth & $\begin{array}{l}-0.74 \\
(0.47)\end{array}$ & $\begin{array}{c}0.30 \\
(0.96)\end{array}$ & $\begin{array}{c}-1.42 * * \\
(0.60)\end{array}$ & $\begin{array}{l}-0.75 \\
(0.48)\end{array}$ & $\begin{array}{c}0.26 \\
(0.98)\end{array}$ & $\begin{array}{c}-1.51^{* * * *} \\
(0.55)\end{array}$ \\
\hline Aging speed & $\begin{array}{l}0.056 \\
(0.06)\end{array}$ & $\begin{array}{c}0.222^{* *} \\
(0.11)\end{array}$ & $\begin{array}{l}-0.142 \\
(0.09)\end{array}$ & $\begin{array}{l}0.046 \\
(0.06)\end{array}$ & $\begin{array}{c}0.222^{*} \\
(0.12)\end{array}$ & $\begin{array}{c}-0.158^{*} \\
(0.09)\end{array}$ \\
\hline Relative GDP per capita & $\begin{array}{c}0.027 * \\
(0.01)\end{array}$ & $\begin{array}{l}0.013 \\
(0.03)\end{array}$ & $\begin{array}{l}0.043 \\
(0.03)\end{array}$ & $\begin{array}{c}0.028^{*} \\
(0.02)\end{array}$ & $\begin{array}{l}-0.005 \\
(0.03)\end{array}$ & $\begin{array}{l}0.041 \\
(0.03)\end{array}$ \\
\hline Lagged NFA & $\begin{array}{c}0.049 * * * \\
(0.01)\end{array}$ & $\begin{array}{c}0.046^{* * *} \\
(0.01)\end{array}$ & $\begin{array}{c}0.050^{* * * *} \\
(0.01)\end{array}$ & $\begin{array}{c}0.050^{* * *} \\
(0.01)\end{array}$ & $\begin{array}{c}0.047 * * * \\
(0.01)\end{array}$ & $\begin{array}{c}0.049^{* * * *} \\
(0.01)\end{array}$ \\
\hline Crisis dummy & $\begin{array}{c}0.018^{* *} \\
(0.01)\end{array}$ & $\begin{array}{l}0.004 \\
(0.01)\end{array}$ & $\begin{array}{c}0.015^{*} \\
(0.01)\end{array}$ & $\begin{array}{c}0.018^{* *} \\
(0.01)\end{array}$ & $\begin{array}{l}0.002 \\
(0.01)\end{array}$ & $\begin{array}{c}0.014^{*} \\
(0.01)\end{array}$ \\
\hline Financial center dummy & $\begin{array}{l}0.014 \\
(0.01)\end{array}$ & $\begin{array}{l}0.022 \\
(0.01)\end{array}$ & & $\begin{array}{l}0.013 \\
(0.01)\end{array}$ & $\begin{array}{l}0.020 \\
(0.01)\end{array}$ & \\
\hline Asian crisis dummy & $\begin{array}{c}0.037 * * * \\
(0.01)\end{array}$ & $\begin{array}{c}0.02 \\
(0.02)\end{array}$ & $\begin{array}{c}0.034^{* *} \\
(0.01)\end{array}$ & $\begin{array}{c}0.035^{* *} \\
(0.01)\end{array}$ & $\begin{array}{l}0.022 \\
(0.02)\end{array}$ & $\begin{array}{c}0.032^{* *} \\
(0.01)\end{array}$ \\
\hline Oil balance & $\begin{array}{c}0.239 * * * \\
(0.06)\end{array}$ & $\begin{array}{c}0.262^{* * *} \\
(0.08)\end{array}$ & $\begin{array}{c}0.214^{* *} \\
(0.10)\end{array}$ & $\begin{array}{c}0.239 * * * \\
(0.06)\end{array}$ & $\begin{array}{c}0.280^{* * *} \\
(0.09)\end{array}$ & $\begin{array}{c}0.232^{* *} \\
(0.09)\end{array}$ \\
\hline Oil balance Norway & $\begin{array}{c}0.14 \\
(0.11)\end{array}$ & $\begin{array}{c}0.14 \\
(0.14)\end{array}$ & & $\begin{array}{l}0.171 \\
(0.13)\end{array}$ & $\begin{array}{c}0.21 \\
(0.25)\end{array}$ & \\
\hline Log terms of trade & & & & $\begin{array}{c}0.0107 \\
(0.01)\end{array}$ & $\begin{array}{c}0.0141 \\
(0.04)\end{array}$ & $\begin{array}{c}0.0161 * \\
(0.01)\end{array}$ \\
\hline Constant & $\begin{array}{l}0.007 \\
(0.01)\end{array}$ & $\begin{array}{l}0.002 \\
(0.01)\end{array}$ & $\begin{array}{l}0.004 \\
(0.02)\end{array}$ & $\begin{array}{l}-0.041 \\
(0.05)\end{array}$ & $\begin{array}{l}-0.067 \\
(0.21)\end{array}$ & $\begin{array}{l}-0.072 \\
(0.05)\end{array}$ \\
\hline Observations & 503 & 234 & 269 & 496 & 227 & 269 \\
\hline $\mathrm{R}^{2}$ & 0.45 & 0.60 & 0.29 & 0.44 & 0.60 & 0.30 \\
\hline
\end{tabular}

Note: Panel estimation, 4-year averages. ${ }^{*}, *, * * *$ denote significance at 10, 5 and 1 percent levels respectively. OLS estimation with robust standard errors. 
Table 2. Current Account Adjustment, 2010 vs 2005-08

\begin{tabular}{|c|c|c|c|c|c|c|c|}
\hline & (1) & (2) & (3) & (4) & (5) & (6) & (7) \\
\hline Sample $\rightarrow$ & All & No Peg & Peg & $\begin{array}{l}\text { No Peg } \\
\text { excl ICE }\end{array}$ & $\begin{array}{l}\text { Peg excl } \\
\text { Baltics }\end{array}$ & All & $\begin{array}{l}\text { All excl } \\
\text { ICE, } \\
\text { Baltics }\end{array}$ \\
\hline CA gap & $\begin{array}{c}-0.57 * * * \\
{[0.12]}\end{array}$ & $\begin{array}{c}-0.44 * * * \\
{[0.07]}\end{array}$ & $\begin{array}{c}-0.84 * * * \\
{[0.19]}\end{array}$ & $\begin{array}{c}-0.39 * * * \\
{[0.07]}\end{array}$ & $\begin{array}{l}-0.58^{*} \\
{[0.30]}\end{array}$ & $\begin{array}{c}-0.44 * * * \\
{[0.07]}\end{array}$ & $\begin{array}{c}-0.39 * * * \\
{[0.07]}\end{array}$ \\
\hline CA gap*peg & & & & & & $\begin{array}{c}-0.40 * * \\
{[0.20]}\end{array}$ & $\begin{array}{l}-0.19 \\
{[0.30]}\end{array}$ \\
\hline NFA/GDP 2004-07 & $\begin{array}{c}-0.01 \\
{[0.01]}\end{array}$ & $\begin{array}{c}0.00 \\
{[0.01]}\end{array}$ & $\begin{array}{l}-0.03^{*} \\
{[0.01]}\end{array}$ & $\begin{array}{c}0.00 \\
{[0.01]}\end{array}$ & $\begin{array}{c}-0.02 \\
{[0.01]}\end{array}$ & $\begin{array}{c}0.00 \\
{[0.01]}\end{array}$ & $\begin{array}{c}0.00 \\
{[0.01]}\end{array}$ \\
\hline NFA $*$ peg & & & & & & $\begin{array}{l}-0.03^{*} \\
{[0.02]}\end{array}$ & $\begin{array}{l}-0.02 \\
{[0.02]}\end{array}$ \\
\hline Peg & & & & & & $\begin{array}{c}0.00 \\
{[0.01]}\end{array}$ & $\begin{array}{l}-0.00 \\
{[0.01]}\end{array}$ \\
\hline constant & $\begin{array}{l}0.01 * * \\
{[0.01]}\end{array}$ & $\begin{array}{l}0.01 * * \\
{[0.00]}\end{array}$ & $\begin{array}{c}0.01 \\
{[0.01]}\end{array}$ & $\begin{array}{l}0.01 * \\
{[0.00]}\end{array}$ & $\begin{array}{c}0.00 \\
{[0.01]}\end{array}$ & $\begin{array}{c}0.01 * * \\
{[0.00]}\end{array}$ & $\begin{array}{l}0.01 * \\
{[0.00]}\end{array}$ \\
\hline $\begin{array}{l}\mathrm{N} \\
\mathrm{R}^{2}\end{array}$ & $\begin{array}{c}65 \\
0.42\end{array}$ & $\begin{array}{c}42 \\
0.44\end{array}$ & $\begin{array}{c}23 \\
0.49\end{array}$ & $\begin{array}{c}41 \\
0.31\end{array}$ & $\begin{array}{c}20 \\
0.38\end{array}$ & $\begin{array}{c}65 \\
0.51\end{array}$ & $\begin{array}{c}61 \\
0.36\end{array}$ \\
\hline
\end{tabular}

Note: The dependent variable is the change in the ratio of the current account to GDP between 2005-08 and 2010. The sample in columns (4) and (7) exclude Iceland; the sample in columns (5) and (7) exclude Estonia, Latvia, and Lithuania. *,*, *** denote significance at 10, 5 and 1 percent levels respectively. OLS estimation with robust standard errors. 
Table 3. Real Exchange Rate Adjustment, 2005-08 to 2010

\begin{tabular}{|c|c|c|c|c|c|c|c|}
\hline & (1) & (2) & (3) & (4) & (5) & (6) & (7) \\
\hline Sample $\rightarrow$ & All & No Peg & Peg & $\begin{array}{l}\text { No Peg } \\
\text { excl ICE }\end{array}$ & $\begin{array}{l}\text { Peg excl } \\
\text { Baltics }\end{array}$ & All & $\begin{array}{l}\text { All excl } \\
\text { ICE, } \\
\text { Baltics }\end{array}$ \\
\hline CA gap & $\begin{array}{c}0.38 \\
{[0.345]}\end{array}$ & $\begin{array}{c}0.67 \\
{[0.425]}\end{array}$ & $\begin{array}{c}-0.50^{* * *} \\
{[0.099]}\end{array}$ & $\begin{array}{c}0.18 \\
{[0.255]}\end{array}$ & $\begin{array}{l}-0.38^{* *} \\
{[0.152]}\end{array}$ & $\begin{array}{c}0.67 \\
{[0.430]}\end{array}$ & $\begin{array}{c}0.18 \\
{[0.259]}\end{array}$ \\
\hline CA gap*peg & & & & & & $\begin{array}{c}-1.17 * * * \\
{[0.441]}\end{array}$ & $\begin{array}{l}-0.56^{*} \\
{[0.298]}\end{array}$ \\
\hline NFA/GDP 2004-07 & $\begin{array}{c}-0.01 \\
{[0.015]}\end{array}$ & $\begin{array}{c}0.02 \\
{[0.014]}\end{array}$ & $\begin{array}{c}-0.04 * * * \\
{[0.009]}\end{array}$ & $\begin{array}{c}0.02 \\
{[0.011]}\end{array}$ & $\begin{array}{c}-0.04 * * * \\
{[0.010]}\end{array}$ & $\begin{array}{c}0.02 \\
{[0.014]}\end{array}$ & $\begin{array}{c}0.02 \\
{[0.011]}\end{array}$ \\
\hline NFA * peg & & & & & & $\begin{array}{c}-0.06^{* * *} \\
{[0.017]}\end{array}$ & $\begin{array}{c}-0.05^{* * *} \\
{[0.014]}\end{array}$ \\
\hline Peg & & & & & & $\begin{array}{l}-0.04^{*} \\
{[0.020]}\end{array}$ & $\begin{array}{c}-0.05^{* * *} \\
{[0.018]}\end{array}$ \\
\hline constant & $\begin{array}{c}0.02 * \\
{[0.012]}\end{array}$ & $\begin{array}{c}0.03 * \\
{[0.017]}\end{array}$ & $\begin{array}{c}-0.01 \\
{[0.009]}\end{array}$ & $\begin{array}{c}0.04^{* * *} \\
{[0.015]}\end{array}$ & $\begin{array}{c}-0.01 \\
{[0.010]}\end{array}$ & $\begin{array}{c}0.03^{*} \\
{[0.017]}\end{array}$ & $\begin{array}{l}0.04 * * * \\
{[0.016]}\end{array}$ \\
\hline $\begin{array}{l}\mathrm{N} \\
\mathrm{R}^{2}\end{array}$ & $\begin{array}{c}65 \\
0.05\end{array}$ & $\begin{array}{c}42 \\
0.15\end{array}$ & $\begin{array}{c}23 \\
0.47\end{array}$ & $\begin{array}{c}41 \\
0.02\end{array}$ & $\begin{array}{c}20 \\
0.38\end{array}$ & $\begin{array}{c}65 \\
0.21\end{array}$ & $\begin{array}{c}61 \\
0.14\end{array}$ \\
\hline
\end{tabular}

Note: The dependent variable is the percentage change in the real effective exchange rate between the 2005-08 average and 2010. The sample in columns (4) and (7) exclude Iceland; the sample in columns (5) and (7) exclude Estonia, Latvia, and Lithuania. *,*, *** denote significance at 10, 5 and 1 percent levels respectively. OLS estimation with robust standard errors. 
Table 4. Demand and Output Adjustment, 2005-08 to 2010

\begin{tabular}{|c|c|c|c|c|c|c|}
\hline & (1) & (2) & (3) & (4) & (5) & (6) \\
\hline Sample $\rightarrow$ & All & No peg & Peg & All & No peg & Peg \\
\hline Dependent var. $\rightarrow$ & \multicolumn{3}{|c|}{ Change in demand } & \multicolumn{3}{|c|}{ Change in output } \\
\hline CA gap & $\begin{array}{l}1.34 * * * \\
{[0.275]}\end{array}$ & $\begin{array}{l}1.30^{* * *} \\
{[0.354]}\end{array}$ & $\begin{array}{c}0.70 \\
{[0.423]}\end{array}$ & $\begin{array}{c}0.75^{* * *} \\
{[0.204]}\end{array}$ & $\begin{array}{c}0.75^{* * *} \\
{[0.218]}\end{array}$ & $\begin{array}{c}0.13 \\
{[0.302]}\end{array}$ \\
\hline NFA/GDP 2004-07 & $\begin{array}{c}0.02 \\
{[0.015]}\end{array}$ & $\begin{array}{c}-0.00 \\
{[0.022]}\end{array}$ & $\begin{array}{c}0.07 * * * \\
{[0.012]}\end{array}$ & $\begin{array}{c}0.02 \\
{[0.011]}\end{array}$ & $\begin{array}{c}0.00 \\
{[0.021]}\end{array}$ & $\begin{array}{l}0.05^{* * *} \\
{[0.012]}\end{array}$ \\
\hline Constant & $\begin{array}{c}0.06 * * * \\
{[0.013]}\end{array}$ & $\begin{array}{c}0.08^{* * *} \\
{[0.014]}\end{array}$ & $\begin{array}{c}-0.01 \\
{[0.018]}\end{array}$ & $\begin{array}{c}0.07 * * * \\
{[0.011]}\end{array}$ & $\begin{array}{c}0.09 * * * \\
{[0.013]}\end{array}$ & $\begin{array}{c}0.02 \\
{[0.013]}\end{array}$ \\
\hline $\mathrm{N}$ & 65 & 42 & 23 & 65 & 42 & 23 \\
\hline $\mathrm{R}^{2}$ & 0.33 & 0.34 & 0.31 & 0.21 & 0.21 & 0.24 \\
\hline
\end{tabular}

Note: Dependent variable is the change in total domestic demand between the 2005-08 average and 2010 in columns (1), (2), and (3) and the change in real GDP between the 2005-08 average and 2010 in columns (4), (5), and (6). CA gap is the difference between actual and fitted value for the CA to GDP ratio, 2005-08. ***,*** denote significance at 10, 5 and 1 percent levels respectively. OLS estimation with robust standard errors. 
Table 5. Crisis outcomes and sign of current account gap

\begin{tabular}{|c|c|c|c|c|c|c|}
\hline Dep. Var. $\rightarrow$ & $\begin{array}{l}\text { (1) } \\
\text { Change in } \\
\text { curr. acct. }\end{array}$ & $\begin{array}{c}\text { (2) } \\
\text { Change in } \\
\text { curr. acct. }\end{array}$ & $\begin{array}{c}\text { (3) } \\
\text { Change in } \\
\text { demand }\end{array}$ & $\begin{array}{c}\text { (4) } \\
\text { Change in } \\
\text { demand }\end{array}$ & $\begin{array}{c}\text { (5) } \\
\text { Change in } \\
\text { output }\end{array}$ & $\begin{array}{c}\text { (6) } \\
\text { Change in } \\
\text { output }\end{array}$ \\
\hline Sample $\rightarrow$ & CA gap $<0$ & CA gap $>0$ & CA gap $<0$ & CA gap $>0$ & CA gap $<0$ & CA gap $>0$ \\
\hline CA gap & $\begin{array}{c}-0.90 * * * \\
{[0.258]}\end{array}$ & $\begin{array}{l}-0.23 * * \\
{[0.097]}\end{array}$ & $\begin{array}{l}1.87^{* * *} \\
{[0.612]}\end{array}$ & $\begin{array}{l}1.02 * * \\
{[0.451]}\end{array}$ & $\begin{array}{c}0.66 \\
{[0.401]}\end{array}$ & $\begin{array}{c}0.65 \\
{[0.409]}\end{array}$ \\
\hline NFA/GDP 2004-07 & $\begin{array}{c}-0.02 \\
{[0.013]}\end{array}$ & $\begin{array}{c}0.00 \\
{[0.010]}\end{array}$ & $\begin{array}{l}0.04 * * \\
{[0.019]}\end{array}$ & $\begin{array}{c}-0.01 \\
{[0.023]}\end{array}$ & $\begin{array}{l}0.02 * * \\
{[0.012]}\end{array}$ & $\begin{array}{c}0.00 \\
{[0.020]}\end{array}$ \\
\hline Constant & $\begin{array}{c}-0.00 \\
{[0.014]}\end{array}$ & $\begin{array}{c}0.00 \\
{[0.007]}\end{array}$ & $\begin{array}{c}0.05 \\
{[0.030]}\end{array}$ & $\begin{array}{c}0.03 \\
{[0.022]}\end{array}$ & $\begin{array}{c}0.03 \\
{[0.020]}\end{array}$ & $\begin{array}{l}0.04 * * \\
{[0.020]}\end{array}$ \\
\hline $\begin{array}{l}\text { Observations } \\
\mathrm{R}^{2}\end{array}$ & $\begin{array}{c}28 \\
0.45\end{array}$ & $\begin{array}{c}37 \\
0.08\end{array}$ & $\begin{array}{c}28 \\
0.37\end{array}$ & $\begin{array}{c}37 \\
0.10\end{array}$ & $\begin{array}{c}28 \\
0.19\end{array}$ & $\begin{array}{c}37 \\
0.06\end{array}$ \\
\hline
\end{tabular}

Note: Dependent variable is the change in the current account balance between 2005-08 and 2010 in columns (1) and (2); the change in total domestic demand between 2007 and 2010 in columns (3) and (4); and the change in real GDP between 2007 and 2010 in columns (5) and (6). The sample in columns (1), (3), and (5) includes countries with a negative CA gap (the difference between actual and fitted value for the CA to GDP ratio) for 2005-08. The sample in columns (2), (4), and (6) includes countries with a positive CA gap for 2005-08.*,*, *** denote significance at 10, 5 and 1 percent levels respectively. OLS estimation with robust standard errors. 
Table 6. Pre-crisis fiscal variables and post-crisis outcomes

\begin{tabular}{|c|c|c|c|c|c|c|c|c|}
\hline Dep. Var. $\rightarrow$ & $\begin{array}{c}\text { (1) } \\
\text { Change } \\
\text { in CA }\end{array}$ & $\begin{array}{c}\text { (2) } \\
\text { Change } \\
\text { in CA }\end{array}$ & $\begin{array}{c}\text { (3) } \\
\text { Change } \\
\text { in } \\
\text { REER }\end{array}$ & $\begin{array}{c}(4) \\
\text { Change } \\
\text { in } \\
\text { REER }\end{array}$ & $\begin{array}{c}\text { (5) } \\
\text { Change } \\
\text { in } \\
\text { demand }\end{array}$ & $\begin{array}{c}\text { (6) } \\
\text { Change } \\
\text { in } \\
\text { demand }\end{array}$ & $\begin{array}{c}\text { (7) } \\
\text { Change } \\
\text { in } \\
\text { output }\end{array}$ & $\begin{array}{c}\text { (8) } \\
\text { Change } \\
\text { in } \\
\text { output }\end{array}$ \\
\hline Sample & All & Peg & All & Peg & All & Peg & All & Peg \\
\hline CA gap & $\begin{array}{c}-0.57^{* * *} \\
{[0.109]}\end{array}$ & $\begin{array}{c}-0.67 * * * \\
{[0.197]}\end{array}$ & $\begin{array}{c}0.35 \\
{[0.361]}\end{array}$ & $\begin{array}{c}-0.48^{* * *} \\
{[0.116]}\end{array}$ & $\begin{array}{l}1.41 * * * \\
{[0.280]}\end{array}$ & $\begin{array}{c}0.53 \\
{[0.393]}\end{array}$ & $\begin{array}{l}0.80^{* * *} \\
{[0.221]}\end{array}$ & $\begin{array}{c}0.17 \\
{[0.316]}\end{array}$ \\
\hline NFA/GDP 2004-07 & $\begin{array}{c}-0.01 \\
{[0.012]}\end{array}$ & $\begin{array}{l}-0.03^{* *} \\
{[0.013]}\end{array}$ & $\begin{array}{c}-0.01 \\
{[0.014]}\end{array}$ & $\begin{array}{c}-0.04 * * * \\
{[0.011]}\end{array}$ & $\begin{array}{c}0.02 \\
{[0.014]}\end{array}$ & $\begin{array}{l}0.07 * * * \\
{[0.018]}\end{array}$ & $\begin{array}{c}0.02 \\
{[0.011]}\end{array}$ & $\begin{array}{l}0.05^{* * *} \\
{[0.015]}\end{array}$ \\
\hline Gov. debt/GDP & $\begin{array}{c}-0.01 \\
{[0.017]}\end{array}$ & $\begin{array}{c}-0.06 \\
{[0.047]}\end{array}$ & $\begin{array}{c}0.02 \\
{[0.032]}\end{array}$ & $\begin{array}{c}-0.01 \\
{[0.036]}\end{array}$ & $\begin{array}{c}-0.05 \\
{[0.047]}\end{array}$ & $\begin{array}{c}0.06 \\
{[0.096]}\end{array}$ & $\begin{array}{c}-0.03 \\
{[0.040]}\end{array}$ & $\begin{array}{c}-0.01 \\
{[0.060]}\end{array}$ \\
\hline Constant & $\begin{array}{c}0.02 \\
{[0.011]}\end{array}$ & $\begin{array}{c}0.04 \\
{[0.028]}\end{array}$ & $\begin{array}{c}0.01 \\
{[0.019]}\end{array}$ & $\begin{array}{c}-0.00 \\
{[0.023]}\end{array}$ & $\begin{array}{l}0.08^{* * *} \\
{[0.027]}\end{array}$ & $\begin{array}{c}-0.03 \\
{[0.058]}\end{array}$ & $\begin{array}{l}0.08^{* * *} \\
{[0.021]}\end{array}$ & $\begin{array}{c}0.02 \\
{[0.036]}\end{array}$ \\
\hline $\begin{array}{l}\text { Observations } \\
\mathrm{R}^{2}\end{array}$ & $\begin{array}{c}65 \\
0.42\end{array}$ & $\begin{array}{c}23 \\
0.53\end{array}$ & $\begin{array}{c}65 \\
0.05\end{array}$ & $\begin{array}{c}23 \\
0.47\end{array}$ & $\begin{array}{c}65 \\
0.34\end{array}$ & $\begin{array}{c}23 \\
0.32\end{array}$ & $\begin{array}{c}65 \\
0.23\end{array}$ & $\begin{array}{c}23 \\
0.24\end{array}$ \\
\hline
\end{tabular}

Note: Dependent variable is the change in the current account balance between 2005-08 and 2010 in columns (1) and (2); the change in the real effective exchange rate between 2005-08 and 2010 in columns (3) and (4); the change in total domestic demand between 2005-08 and 2010 in columns (5) and (6); and the change in real GDP between 2005-08 and 2010 in columns (7) and (8). Sample for columns (1), (3), (5), and (7) includes all countries; sample for columns (2), (4), (6), and (8) include countries with a de facto peg. ${ }^{*}, * *, * *$ denote significance at 10,5 and 1 percent levels respectively. OLS estimation with robust standard errors. 
Table 7. Current account gap and capital flow adjustment by exchange rate regime

\begin{tabular}{|c|c|c|c|c|}
\hline Sample $\rightarrow$ & $\begin{array}{c}\text { Large } \\
\text { negative CA } \\
\text { gap 2005-08 } \\
(<-2 \% \text { of } \\
\text { GDP) }\end{array}$ & $\begin{array}{c}\text { Large } \\
\text { positive CA } \\
\text { gap 2005-08 } \\
(>2 \% \text { of } \\
\text { GDP) }\end{array}$ & $\begin{array}{c}\text { Large } \\
\text { negative CA } \\
\text { gap 2005-08 } \\
(<-2 \% \text { of } \\
\text { GDP) }\end{array}$ & $\begin{array}{c}\text { Large } \\
\text { positive CA } \\
\text { gap } 2005-08 \\
(>2 \% \text { of } \\
\text { GDP) }\end{array}$ \\
\hline exchange rate regime & \multicolumn{2}{|c|}{ Peg } & \multicolumn{2}{|c|}{ No peg } \\
\hline Current account gap 2005-08 & -5.0 & 4.7 & -4.5 & 5.2 \\
\hline Current account balance, 2010 vs $2005-08$ & 5.6 & -0.5 & 4.9 & -0.1 \\
\hline Change in net other inv. flows, 2010 vs $2005-08$ & -8.8 & 5.2 & 2.5 & 0.0 \\
\hline Change in net direct inv. flows, 2010 vs $2005-08$ & -0.9 & -1.2 & 1.0 & 0.0 \\
\hline Change in net portf. inv. flows, 2010 vs $2005-08$ & 1.9 & -2.6 & -8.6 & 1.9 \\
\hline Change in FX reserve flows, 2010 vs 2005-08 & 1.5 & -0.0 & -0.7 & -1.8 \\
\hline Number of observations & 13 & 4 & 9 & 20 \\
\hline
\end{tabular}

Source: authors' calculations based on International Monetary Fund, Balance of Payments Statistics. 
Table 8. Change in capital flows and current account gap

\begin{tabular}{|c|c|c|c|c|c|c|c|c|}
\hline \multirow{3}{*}{$\begin{array}{l}\text { Dep var } \rightarrow \\
\text { Sample } \rightarrow\end{array}$} & (1) & (2) & (3) & \multirow{3}{*}{$\begin{array}{c}\text { (4) } \\
\text { Change } \\
\text { in FDI } \\
\text { flows } \\
\text { All }\end{array}$} & \multirow{3}{*}{$\begin{array}{l}\text { (5) } \\
\text { Change in } \\
\text { portfolio } \\
\text { flows } \\
\text { All }\end{array}$} & \multirow{2}{*}{\multicolumn{3}{|c|}{$\begin{array}{c}(6) \\
\text { Change in reserve flows }\end{array}$}} \\
\hline & \multicolumn{3}{|c|}{$\begin{array}{c}\text { Change in other investment } \\
\text { flows }\end{array}$} & & & & & \\
\hline & All & No peg & Peg & & & All & No peg & g Peg \\
\hline CA gap & $\begin{array}{l}0.56^{* *} \\
{[0.265]}\end{array}$ & $\begin{array}{c}0.11 \\
{[0.195]}\end{array}$ & $\begin{array}{l}1.11^{* * *} \\
{[0.371]}\end{array}$ & $\begin{array}{c}0.16 \\
{[0.160]}\end{array}$ & $\begin{array}{c}0.09 \\
{[0.211]}\end{array}$ & $\begin{array}{c}-0.10 \\
{[0.140]}\end{array}$ & $\begin{array}{c}0.11 \\
{[0.162]}\end{array}$ & $\begin{array}{c}-0.23 * \\
{[0.115]}\end{array}$ \\
\hline NFA 2004-07 & $\begin{array}{l}0.05^{* *} \\
{[0.022]}\end{array}$ & $\begin{array}{l}0.03^{* *} \\
{[0.012]}\end{array}$ & $\begin{array}{c}0.06 \\
{[0.040]}\end{array}$ & $\begin{array}{c}0.01 \\
{[0.010]}\end{array}$ & $\begin{array}{c}-0.01 \\
{[0.025]}\end{array}$ & $\begin{array}{c}-0.04 \\
{[0.024]}\end{array}$ & $\begin{array}{l}-0.07^{* *} \\
{[0.026]}\end{array}$ & $\begin{array}{c}-0.01 \\
{[0.012]}\end{array}$ \\
\hline Constant & $\begin{array}{c}-0.01 \\
{[0.014]}\end{array}$ & $\begin{array}{c}-0.00 \\
{[0.008]}\end{array}$ & $\begin{array}{c}-0.01 \\
{[0.029]}\end{array}$ & $\begin{array}{c}-0.01 \\
{[0.005]}\end{array}$ & $\begin{array}{c}0.02 \\
{[0.014]}\end{array}$ & $\begin{array}{l}-0.02 * \\
{[0.009]}\end{array}$ & $\begin{array}{c}-0.03 * * * \\
{[0.012]}\end{array}$ & $\begin{array}{c}0.00 \\
{[0.006]}\end{array}$ \\
\hline $\begin{array}{l}\text { Observations } \\
\mathrm{R}^{2}\end{array}$ & $\begin{array}{c}64 \\
0.16\end{array}$ & $\begin{array}{c}41 \\
0.13\end{array}$ & $\begin{array}{c}23 \\
0.23\end{array}$ & $\begin{array}{c}64 \\
0.07\end{array}$ & $\begin{array}{c}64 \\
0.01\end{array}$ & $\begin{array}{c}64 \\
0.23\end{array}$ & $\begin{array}{c}41 \\
0.41\end{array}$ & $\begin{array}{c}23 \\
0.21\end{array}$ \\
\hline $\begin{array}{l}\text { Note: change } \\
2007 \text { (as a ratic } \\
\text { capital outflow } \\
\text { with robust stan } \\
\text { Source: Internat }\end{array}$ & $\begin{array}{l}\text { capital fl } \\
07 \text { GDI } \\
\text { *** den } \\
\text { rrors. } \\
\text { Monetary }\end{array}$ & $\begin{array}{l}\text { ws defin } \\
\text { Net cap } \\
\text { e signific } \\
\text { und, Bala }\end{array}$ & $\begin{array}{l}\text { as the d } \\
\text { al flows } \\
\text { ce at } 10 \text {, } \\
\text { ce of Pay }\end{array}$ & $\begin{array}{l}\text { fferenc } \\
\text { tre the } \\
\text { and } 1\end{array}$ & $\begin{array}{l}\text { etween } 1 \\
\text { erence b } \\
\text { ent level } \\
\text { tics. }\end{array}$ & $\begin{array}{l}\text { capital } \\
\text { ween cal } \\
\text { espective }\end{array}$ & $\begin{array}{l}\text { Ows in } \\
\text { ital inflo } \\
\text { OLS es }\end{array}$ & $\begin{array}{l}010 \text { and } \\
\text { vs and } \\
\text { imation }\end{array}$ \\
\hline
\end{tabular}


Table 9. Current account adjustment, external finance, and current account gap

\begin{tabular}{|c|c|c|c|c|c|}
\hline Sample $\rightarrow$ & (1) & $\begin{array}{c}\text { (2) } \\
\text { Non- } \\
\text { peg }\end{array}$ & (3) & $\begin{array}{c}(4) \\
\text { Non- } \\
\text { peg excl. } \\
\text { Iceland }\end{array}$ & $\begin{array}{c}\text { (5) } \\
\text { Peg } \\
\text { excluding } \\
\text { Latvia }\end{array}$ \\
\hline Current account gap, 2005-08 & $\begin{array}{c}-0.59 * * * \\
{[0.12]}\end{array}$ & $\begin{array}{c}-0.33 * * * \\
{[0.07]}\end{array}$ & $\begin{array}{c}-1.00^{* * *} \\
{[0.20]}\end{array}$ & $\begin{array}{c}-0.31 * * * \\
{[0.07]}\end{array}$ & $\begin{array}{c}-0.83^{* * *} \\
{[0.10]}\end{array}$ \\
\hline NFA to GDP, 2004-2007 & $\begin{array}{l}-0.01 \\
{[0.01]}\end{array}$ & $\begin{array}{c}0.00 \\
{[0.01]}\end{array}$ & $\begin{array}{c}-0.03 * * * \\
{[0.01]}\end{array}$ & $\begin{array}{c}0.00 \\
{[0.01]}\end{array}$ & $\begin{array}{c}-0.03^{* * *} \\
{[0.01]}\end{array}$ \\
\hline External finance dummy & $\begin{array}{l}-0.01 \\
{[0.02]}\end{array}$ & $\begin{array}{l}0.04 * * \\
{[0.02]}\end{array}$ & $\begin{array}{l}-0.06^{*} \\
{[0.03]}\end{array}$ & $\begin{array}{c}0.04 * * \\
{[0.02]}\end{array}$ & $\begin{array}{c}-0.08^{* *} \\
{[0.03]}\end{array}$ \\
\hline Constant & $\begin{array}{c}0.01 * * \\
{[0.01]}\end{array}$ & $\begin{array}{c}0.00 \\
{[0.00]}\end{array}$ & $\begin{array}{l}0.02 * * \\
{[0.01]}\end{array}$ & $\begin{array}{c}0.00 \\
{[0.00]}\end{array}$ & $\begin{array}{c}0.02^{* * *} \\
{[0.01]}\end{array}$ \\
\hline $\begin{array}{l}\text { Observations } \\
\mathrm{R}^{2}\end{array}$ & $\begin{array}{c}65 \\
0.42\end{array}$ & $\begin{array}{c}42 \\
0.56\end{array}$ & $\begin{array}{c}23 \\
0.61\end{array}$ & $\begin{array}{c}41 \\
0.45\end{array}$ & $\begin{array}{c}22 \\
0.68\end{array}$ \\
\hline
\end{tabular}

Note: Dependent variable is the change in the current account balance/GDP ratio between 2005-08 and 2010. The current account gap is the difference between actual and fitted value for the CA to GDP ratio, 2005-08. The "external finance dummy" takes the value of 1 for countries receiving net external official finance during the 2008-2010 period in the form of IMF loans, EU loans, or ECB liquidity provision to banks. The countries are Belarus, Greece, Hungary, Iceland, Ireland, Latvia, Portugal, Serbia, Romania, Spain, and Ukraine. ${ }^{* * *},{ }^{* * *}$ denote significance at 10, 5 and 1 percent levels respectively. OLS estimation with robust standard errors. 
Table 10. Euro Periphery: Net Capital Flows Via Central Banks

\begin{tabular}{|lcc|}
\multicolumn{1}{c}{} & \multicolumn{1}{c}{ Net Capital Flows Via Central Banks } \\
\hline Greece & $2005-2007$ & 2010 \\
\cline { 2 - 3 } Portugal & -0.1 & 22.0 \\
Spain & -0.3 & 16.9 \\
Ireland & -0.5 & 2.3 \\
& -1.0 & 53.6 \\
\hline
\end{tabular}

Note: Ratios to GDP. Calculated from IMF's Balance of Payments Statistics and External Debt statistics for Ireland. 
Figure 1. Standard Deviation of Current Account Balances, 1990-2010

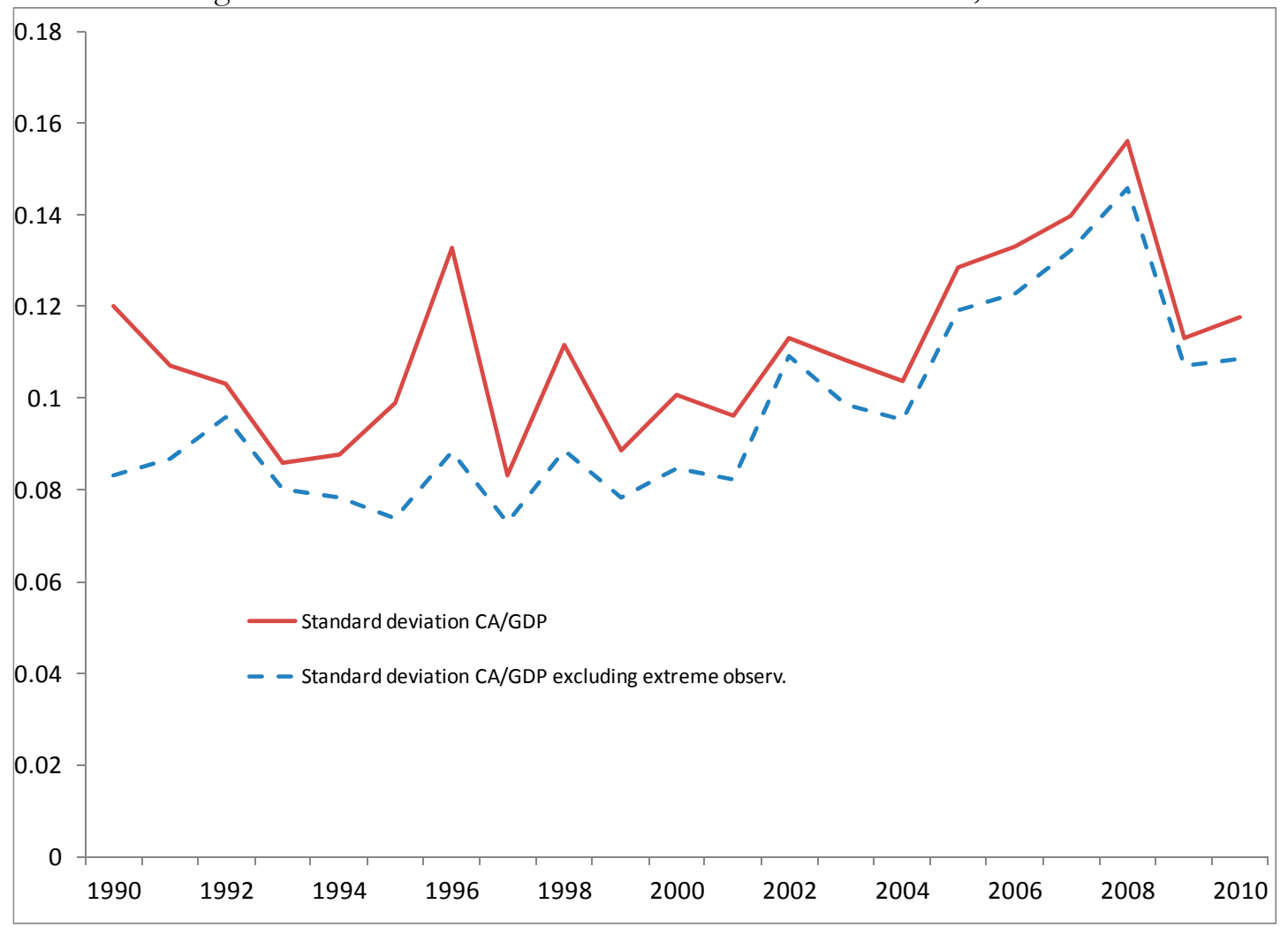

Note: Cross-country standard deviation of current account balances (ratios to GDP). Sample excludes Timor Leste. Sample excluding extreme observations (blue line) also excludes Brunei Darussalam, Equatorial Guinea, Kuwait, Nicaragua, and Qatar.

Source: International Monetary Fund, International Financial Statistics and World Economic Outlook databases. 
Figure 2. Change in current account/GDP ratio, 2007-2010

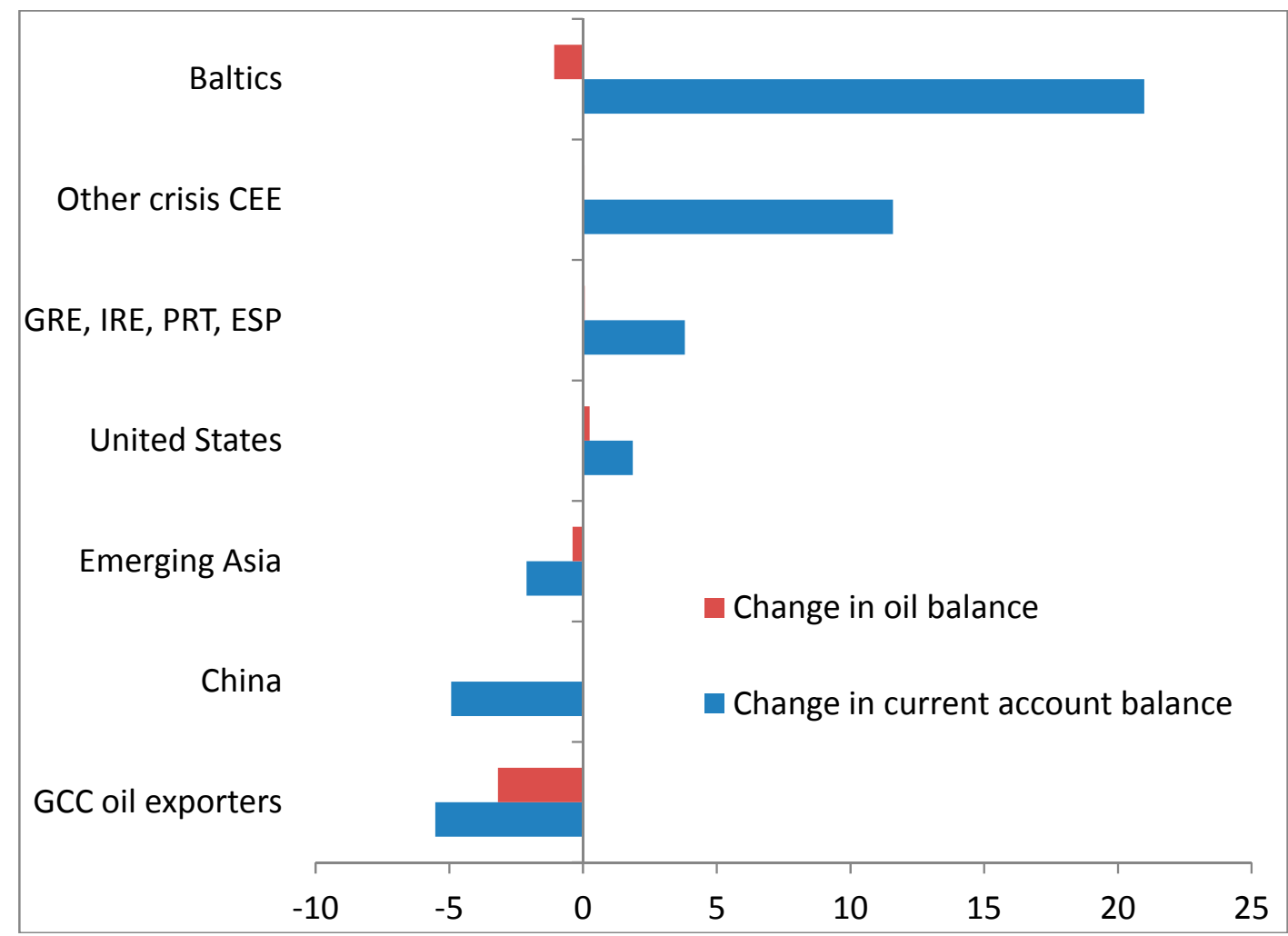

Note: country groups defined as follows:

GRE, IRE, PRT, ESP: Greece, Ireland, Portugal, and Spain (simple average)

Other crisis CEE: Bulgaria, Hungary, Romania, Serbia, Ukraine (simple average)

Emerging Asia: Hong Kong, India, Indonesia, Korea, Malaysia, Philippines, Singapore, Taiwan, Thailand (simple average).

GCC oil exporters: Bahrain, Kuwait, Oman, Qatar, United Arab Emirates, Saudi Arabia (simple average) 
Figure 3. Actual Current Account Balance and Fitted Current Account Balance, 2005-2008

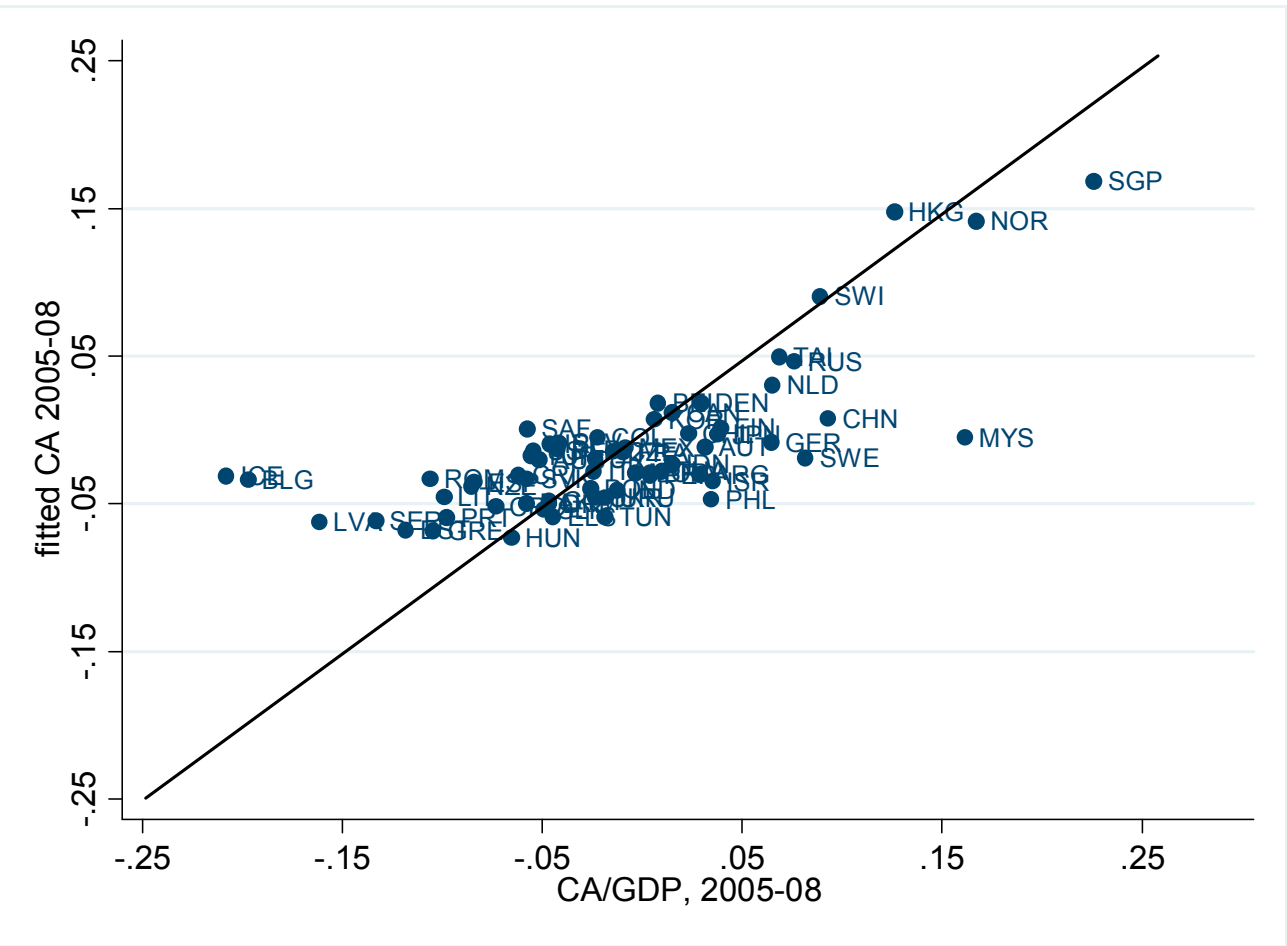

Note: Scatter of actual current account balance against fitted current account balance (average ratios to GDP, 2005-2008). Fitted values based on regression reported in column (4) of Table 1. 
Figure 4. Change in Current Account Balance and Current Account Gap

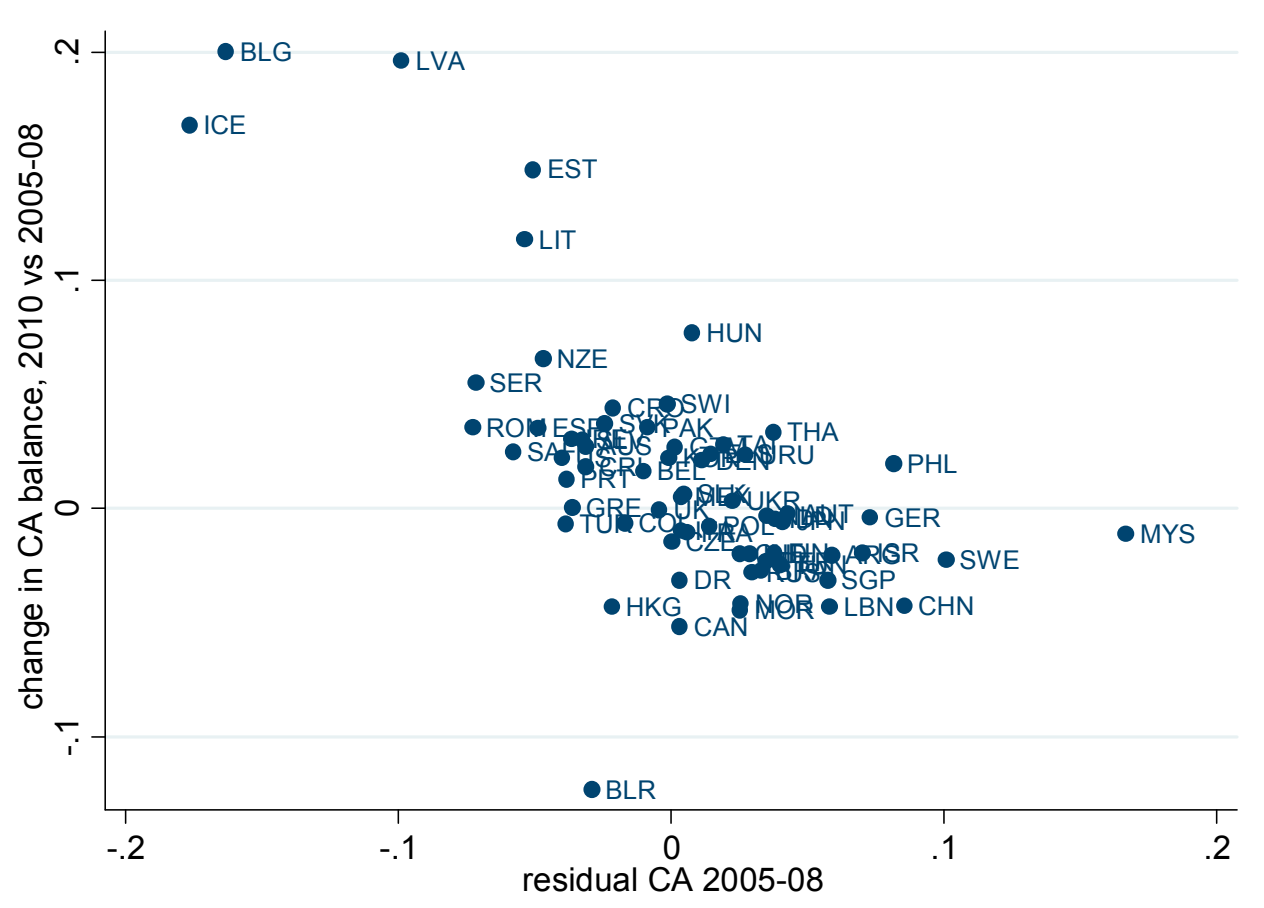

Note: Scatter of changes in the current account balance between 2005-08 and 2010 against the 2005-08 residual from the current account balance regression reported in column (1) of Table 1. 
Figure 5. Current account/GDP and real exchange rate: change between 2005-08 and 2010

A. No peg

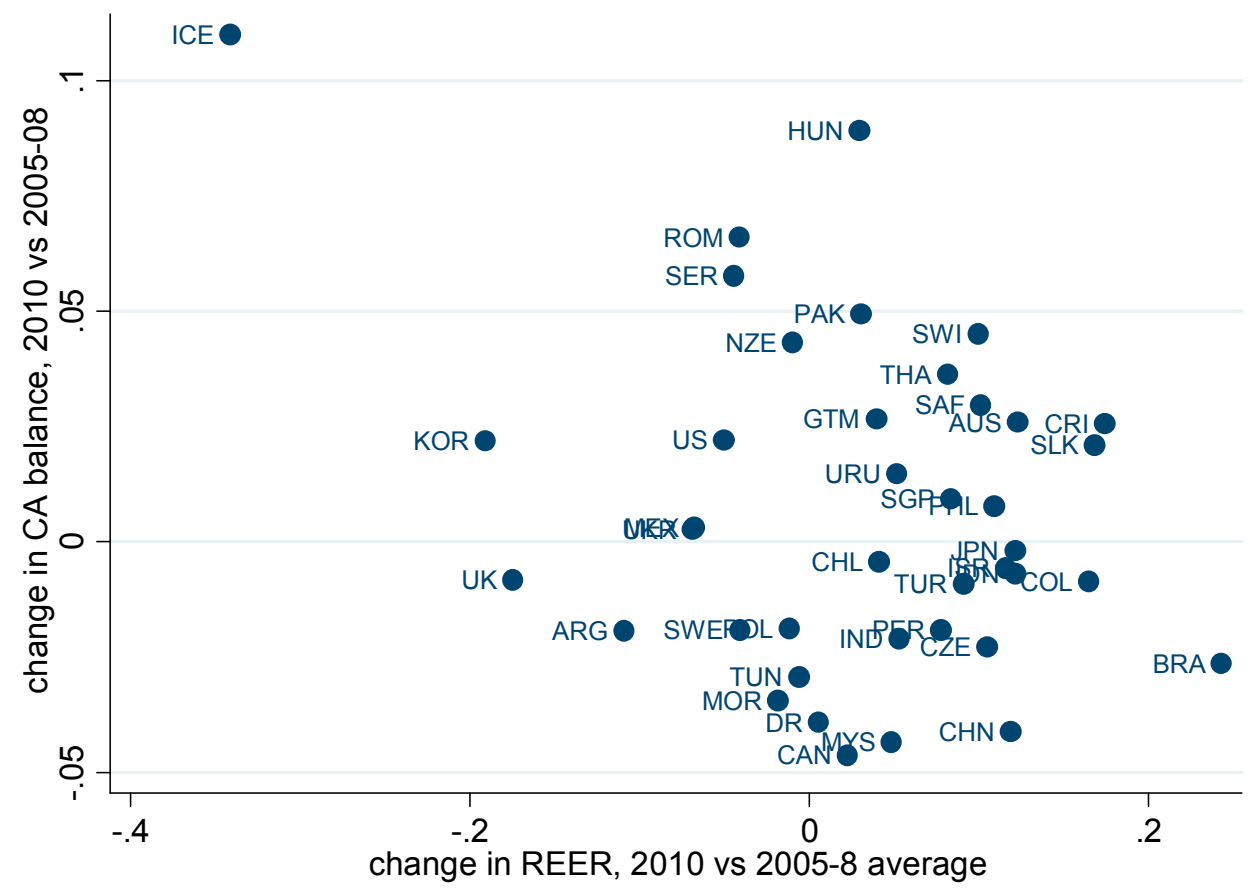

B. Peg

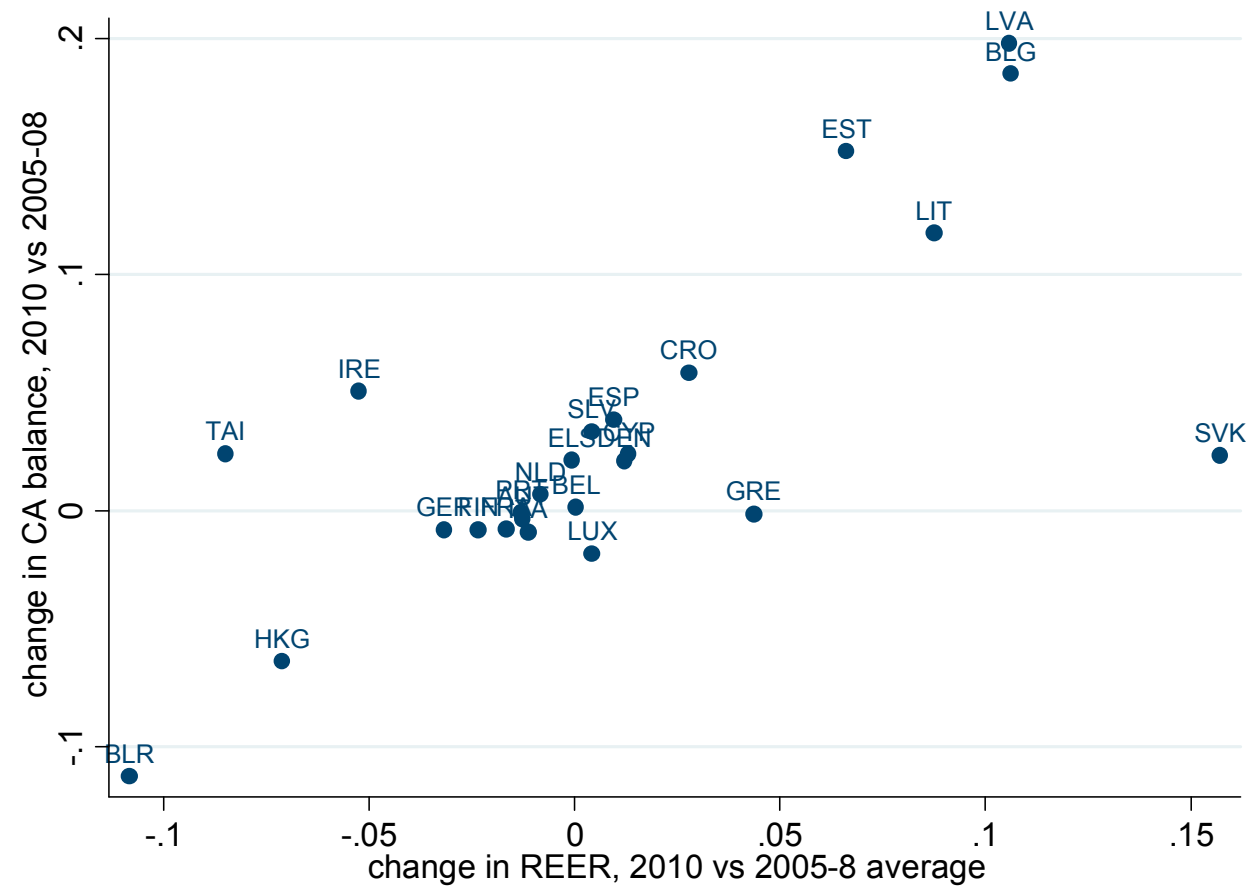

Note: "change in REER 2010 vs 2005-08 average" is the log change in the CPI-based real effective exchange rate index between the 2005-08 average and 2010. "Change in CA balance, 2010 vs 2005-08" is the difference between the CA/GDP ratio in 2010 and the 2005-08 average. Source: authors' calculations based on International Monetary Fund, International Financial Statistics, Balance of Payments Statistics, World Economic Outlook. 
Figure 6. Current account/GDP and real domestic demand, change 2005-08 to 2010

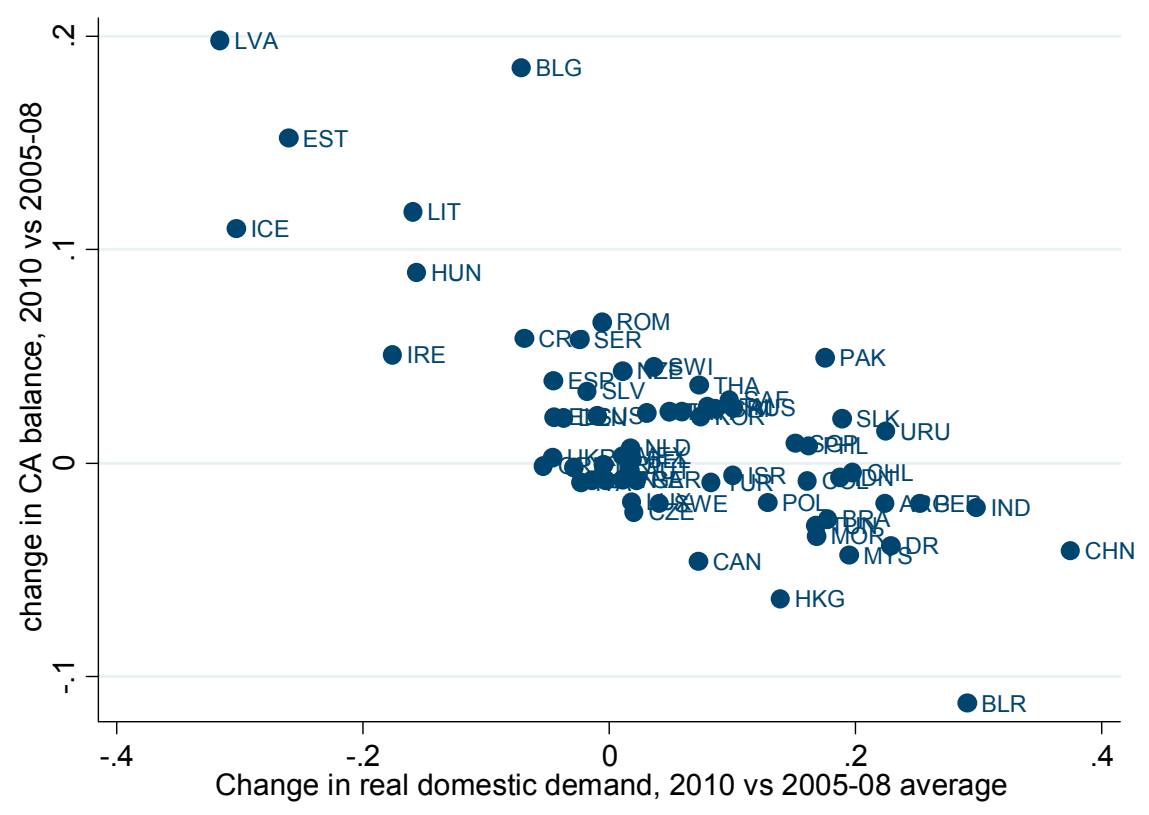

Figure 7. Current account/GDP and real output, change 2005-08 to 2010

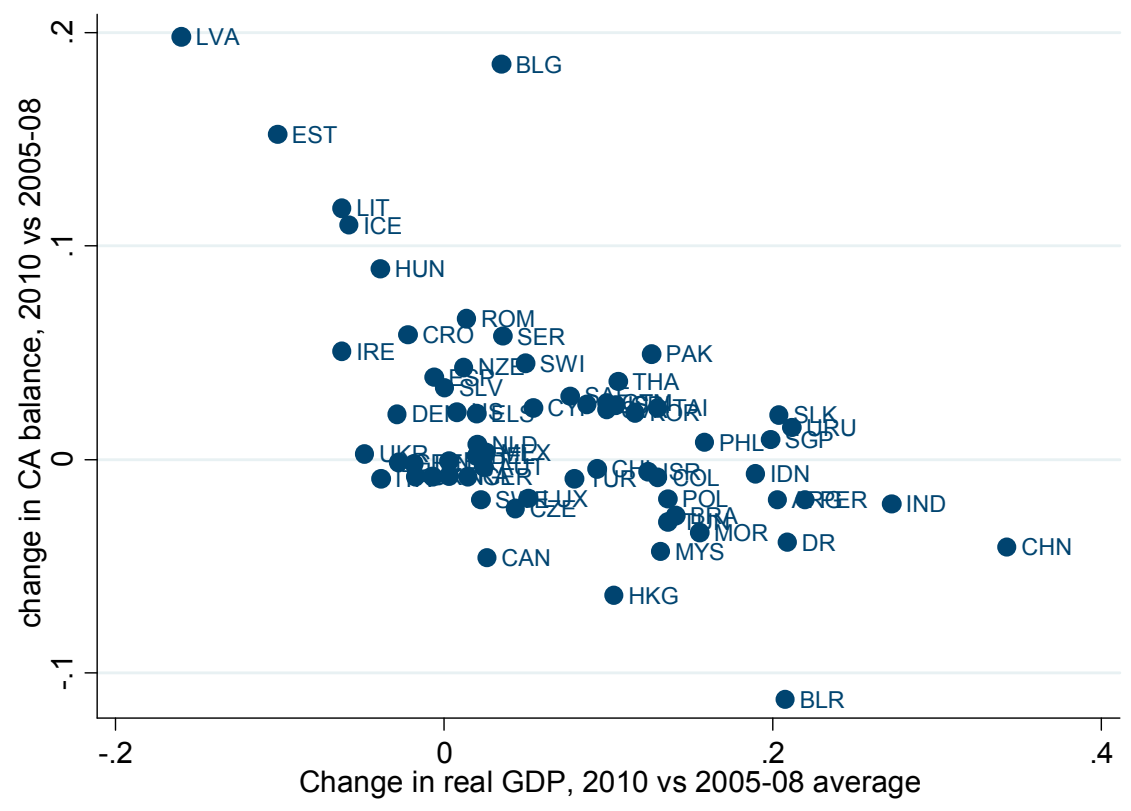

Note to Figures 6-7: "change in real domestic demand, 2010 vs 2005-08 average" is the log change in real domestic demand between the 2005-08 average and 2010. The change in real GDP, 2005-08 to 2010 is defined analogously. "Change in CA balance, 2010 vs 2005-08" is the difference between the CA/GDP ratio in 2010 and the 2005-08 average. Source: authors' calculations based on International Monetary Fund, Balance of Payments Statistics and World Economic Outlook. 
Figure 8. Emerging markets: net capital inflows, 2005-10

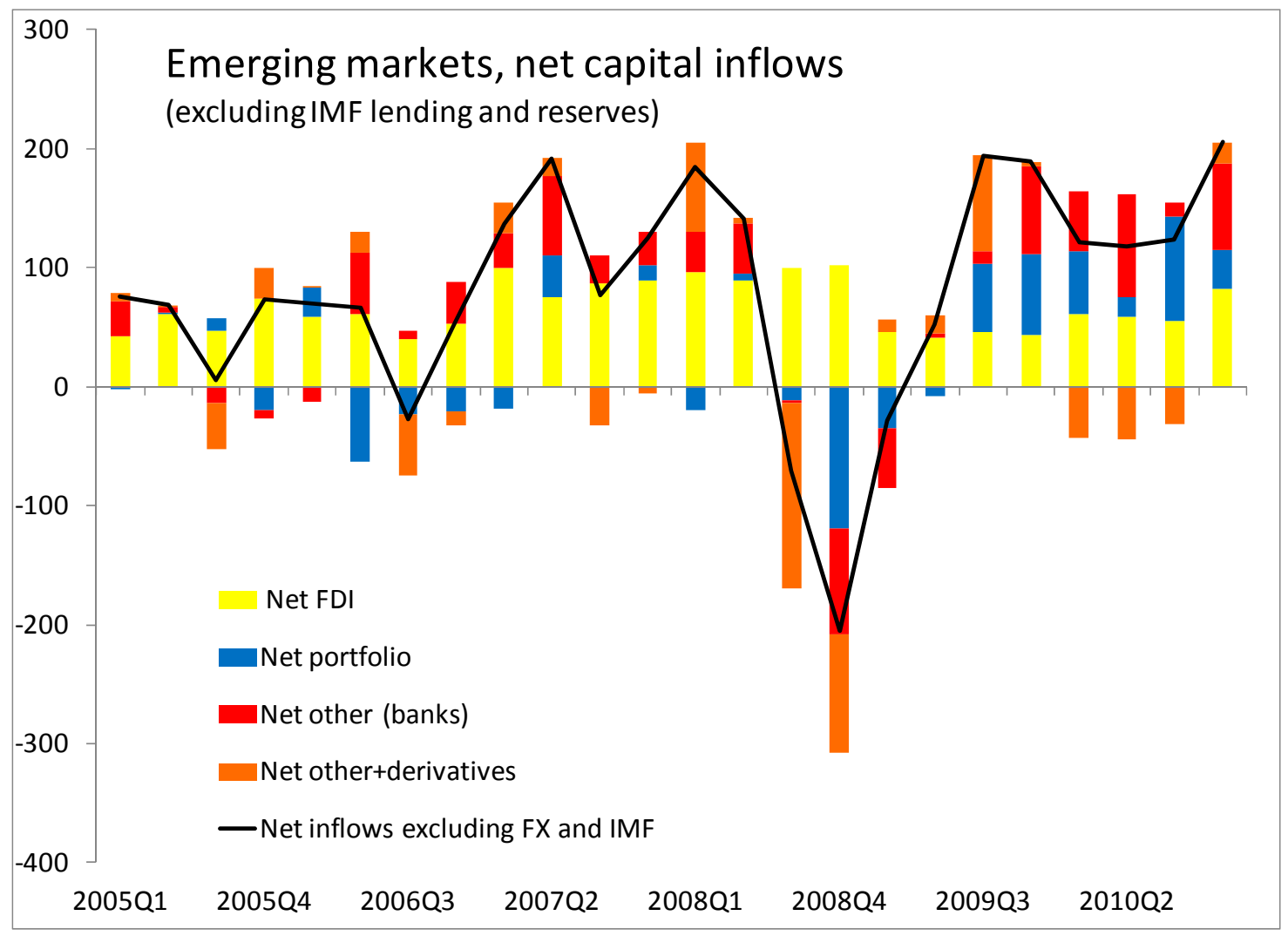

Note: sample includes Argentina, Brazil, Chile, Colombia, Costa Rica, Ecuador, El Salvador, Guatemala, Mexico, Paraguay, Peru, Uruguay, Venezuela, China, Hong Kong, India, Indonesia, Korea, Malaysia, Philippines, Singapore, Taiwan, Thailand, Vietnam, Albania, Belarus, Bulgaria, Croatia, Czech Republic, Estonia, Hungary, Latvia, Lithuania, Poland, Romania, Russia, Serbia, Slovak Republic, Turkey, Ukraine, Armenia, Azerbaijan, Israel, Kazakhstan, Lebanon, Morocco, Pakistan, South Africa, and Saudi Arabia. 